\title{
原著
}

\section{習慣的閉口運動における実験的早期接触の位置が 顎機能に及ぼす影響}

\author{
鯉 㴊 秀 明

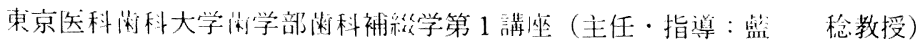 \\ （1989年12月20日受付）

\section{Effects of Positions of Experimental Premature Contacts on Jaw Function}

\section{Hideaki Koibuchi}

The First Department of Prosthodontics, Faculty of Dentistry, Tokyo Medical and Dental University

(Director : Prof. Minoru Ai)

The effects of different positions of experimental premature contacts on the jaw function were investigated on 6 subjects.

The metal castings of $100-\mu \mathrm{m}$ thickness were fabricated to make experimental premature contacts on each of 4 mandibular posterior teeth (from the first premolar to the second molar on the preferable masticatory side).

The EMG activity of the masseter, anterior and posterior temporal muscles during maximum clenching and gum chewing as well as the mandibular movement during gum chewing were evaluated.

The experimental premature contacts reduced the muscle activity, especially on the contralateral side during maximum clenching.

As the premature contact was moved more posteriorly, the following results were observed.

1. The activity of the posterior temporal muscle was decreased on the ipsilateral side while it increased on the contralateral side during maximum clenching in many subjects.

2. The duration of the occlusing phase during the ipsilateral chewing was shortened in many subjects.

3. During ipsilateral chewing, a larger muscle activity was produced during the closing phase and the muscle activity produced during the occlusing phase was the least on the first molar.

4. In any chewing side, the closing and opening paths tended to go toward the chewing side.

\section{I. 緒言}

顎機能異常の局所的因子の一つとして早期接触 があげられる1)。早期接触についてはこれまで, 咀嚼筋2 30), 顎関節 ${ }^{19)}$, 下顎 運動 ${ }^{19,24)}$, 内分泌
系 ${ }^{31)}$, 雨の脈動11や動摇 ${ }^{32}$ などとの関係から多数 娭討され，顎口腔系に少なから奴影響を与えるこ とが明らかにされている。Ramf jord ${ }^{33}$ は中心咬 合位と中心位での早期接触が最も悪影䇾を及ぼ し，ついで平衡側の早期接触であると述べてい 
る。藍1)も咬合異常ぱの作用頻度が高く, そこ で力が加わるよらなものであるほど䪽機能への影 橉は大きく，てのため收頭炭合位やその付近で又 ら机る早期接触は他の下顎位や下顎運動時の接触 異常に比べて影偣は大きいと述べている。つま 门, 咬頭嵌合位付近での早期接触が顎機能上重要 視されているが, 健米行水札てきた早期接触に関 する実験的研究でも，咬頭伀合位を対象としたも のが多い。しかし早期接触の部位としては第一大

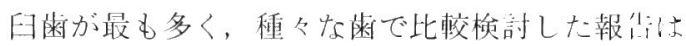
少ない。

ここで本研究ては，咬頭胡合位を保持している

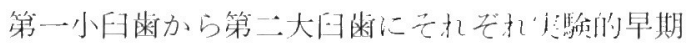
接触を付与し, その位置の違いが咀嚼筋および咀

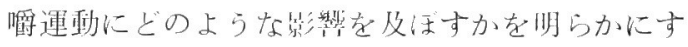
ることを目的として惞讨老陚及た。

\section{II. 研究方法}

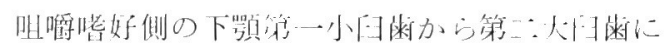

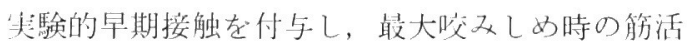
動抢よびガム咀嚼時の筋活軗と下顎運動を記録测 定し，検㴻老行った。

\section{1. 被験者}

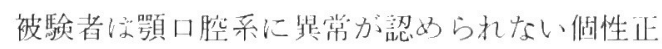

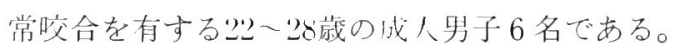

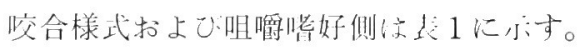

\section{2. 実験的早期接触装置}

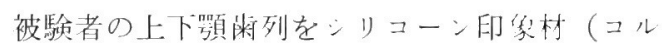
テックス, Coltene 社製) で印堡採得し，超硬石

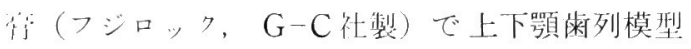
をまず製作した。潾列模型を咬合器に装着後, 咀

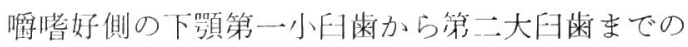
4粎について，舌側咬頭を谁らアンレー状の早期 揬触装置（图1）をりックスアックし，金銀バラ ジウム合金で鋳造した。早期接触の䖯は，口腔内

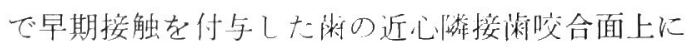
狩当 $100 \mu \mathrm{m}$ に束权た咬合唡查用メタルストリッ プフ（厚さ $13 \mu \mathrm{m}$, Artus 社製）を置き，頨慣的 网いこせて引き拔きを行いこのストリッブスが

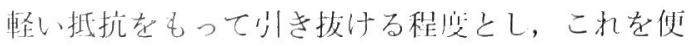

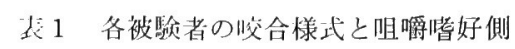

\begin{tabular}{|c|c|c|c|c|c|}
\hline & & & & 咬合様式 & 咀㩊嗜好側 \\
\hline 被 & 験 & 者 & A & $\mathrm{C} \mathrm{G}$ & 左 \\
\hline 被 & 験 & 者 & $\mathrm{B}$ & $\mathrm{C} \mathrm{G}$ & 右 \\
\hline 被 & 駼 & 者 & $\mathrm{C}$ & GF & 右 \\
\hline 被 & 験 & 者 & $\mathrm{D}$ & G F & 左 \\
\hline 被 & 频 & 者 & $\mathrm{E}$ & G F & 右 \\
\hline 被 & 駼 & 者 & $\mathrm{F}$ & GF & 左 \\
\hline
\end{tabular}

CG : Canine guidance

GF : Group function

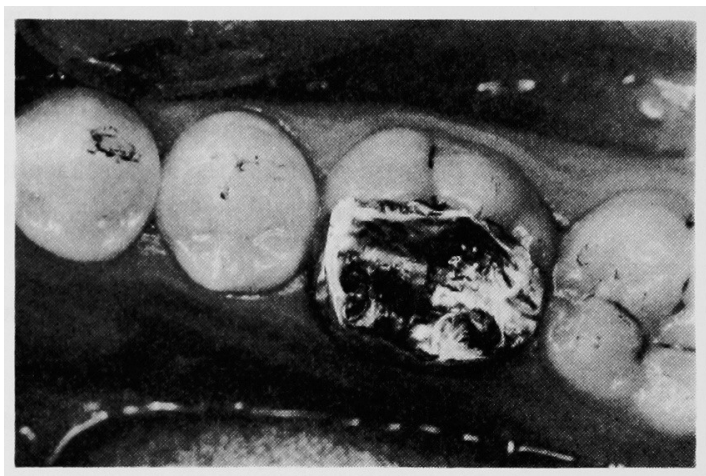

图 1 下罘第一・大臼幽に付与した早期接触装置

宜上 $100 \mu \mathrm{m}$ とした。な扮，第一小四歯について は犬迷での接触がない場合があるため，咬合娭査 用ストリップー1枚を用いて引き抜きを行い, 早 期接触老第二小四雪に付与したときと同じ程度と した。また側方滑走連動時には早期接触装置はで きるだけ㨦触しないよう調整を行った。

\section{3. 筋電図測定装置}

1) 被験笳および導出方法

対象とした被験筋㧍よび部位は，左右の咬筋浅 部 ( $\mathrm{L}-\mathrm{Mm}, \mathrm{R}-\mathrm{Mm}$ ), 側頭筋前部 ( $\mathrm{L}-\mathrm{Ta}, \mathrm{R}-\mathrm{Ta}$ ) および側頭筋後部 ( L-Tp, R-Tp)の 6 筋である。

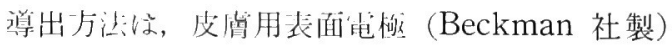
を用いた双極導出とし，電極沙間距離 $15 \mathrm{~mm}$ で闭面接着カラー（日本光電社製）によって筋の 拝行と怡行になるように固定した。アース電極は 两耳梁に呫付し，䉓極間抵抗佔をできるだけ下げ゚ 
るため電極を固定する前に皮虞前処理材（スキン ピュア, 日本光電社製）とアルコールにより皮虞 を十分に清拭した。

\section{2) 增 幅}

表面電極により導出された筋活動電位は, 生休 電気現象用增幅器 (1253A 型, 日本電気三栄社 製）により増幅した。増幅器の時定数は $0.03 \mathrm{sec}$ とし， $1 \mathrm{kHz}$ のハィットフィルターを介在さ せハムフィルターは使用しなかった。増幅度は $500 \mu \mathrm{V}$ の入力に対して, 感熱型才ムニュータ ( 8 MI4，日本電気三栄社製）の振れが $10 \mathrm{~mm}$ にな るようにした。

\section{4. 下䫓運動測定装置}

ガム咀嚼時の下顎運動の記録にはサホン・ビジ トレーナー（東京歯材社製）を用いて，下顎切籶 点部前方約 $10 \mathrm{~mm}$ の測定点の動きを下顎運動と して前頭面で記録した。サホン・ビジトレーナー の信号は生体電気現象用增幅器に送门筋活動々问 時記録するとともに，デジタルレコーダ (CMT2, 東京雨材社製）にも記録した。なお，発光素 子の装着は通法 ${ }^{34)} に$ 従い，下顎歯列模型上で製作 した常温重合レジン製のスプリントを介して下顎 切歯部に固定した。

\section{5. 実験方法}

1）早期接触装置の装着

早期接触装置の装着にはシアノアクリレート系 接着剂（アロンアルファ，東亚合成化学社製）を 用いて逐次 1 歯ずつ固定した。付与する順序が果 験結果に影響を及ぼさないよらに，付与する順序 はランダムとした。

\section{2）筋活動の测定}

被験者を歯科用治療椅子にすわらせ，フランク フルト平面が水平となるよう安頭台を調整した。

(1) 翼慣的閉口位での最大咬久しめ（以下，最 大咬文し的)

咬頭嵌合位において，また各歯に早期接触を付 与したのち習慣的閉口位において, 約 5 秒間の最 大咬みしめを 5 回行わせた。なお, 疲労による影 響をさけるため各咬みしめの間に 3 分間, また早 期接触装置交換時には 5 分間の休賭をとった。
(2) ガム咀㩊

早期接触を付与する前上各歯に早期接触を付与 した後に，軟化したガム（フリージーン，口ッテ 社製）の左右側指示咀嚼を行わせた。すなわち， 早期接触付与後は付与した側 (付与側), 付与し てない側（非付与側）で咀嚼を行わせた。乞して 咀緭開始後 5 ストローク以降の 15 ストロークを分 析の対象とした。

\section{3）下顎運動の測定}

ガム咀嚼について， +ホン・ビジトレーナーを 用いて能頭面での下顎運動を筋活動と同時記録し た。

得られた筋活動と下颚運動の記録は、データレ ンーダ(KS-616型，ソニーマグネスール社製） にテー・涑度 $4.8 \mathrm{~cm} / \mathrm{sec}$ で収録するとともに， 感熱型才ムニュータでモ二タした。なお，最大賋 みしめとガ么咀嚼は被験者の负担を軽減するため 日を変只て行った。

4) 渭定絬果の分析

(1) 筋活動

(1) 最大咬又しめ

データレコーダに收録した朌活動は间テー・上 に部録されたトりガ信号を合四に，12 bit の A/ $\mathrm{D}$ ユン゙ンーータ ( $\mathrm{PCN}-2198$ ，不オローグ電子社製 によりサンクリンダタイム $300 \mu \mathrm{sec} て ゙ \mathrm{~A} / \mathrm{D}$ 変換後，ハーソナルコンピュータ（PC-9801F，

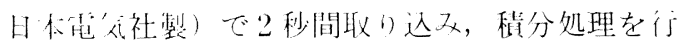
い1秒間あたりの俏に換算した。

(2) ガ八咀絪

サホン・ビジトレーナーによって就録した下唨

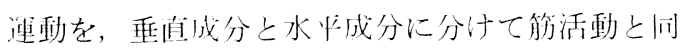
時に再生した。ジグナルブロセッサ（7T18A，

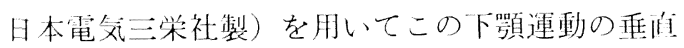
成分より閉口相時間, 咬合相時間および開口相時 間，さらに閉口筋の活動が著明な閉山相と咬合相 における筋活動量を測定した。

なお，閉口相は最大開口位から变曲点まで，咬 合相は閉口時の変曲点から開山時の変曲点まで,

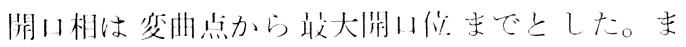
た，筋活䣦についてはサンンリングタイム $500 ル$ 


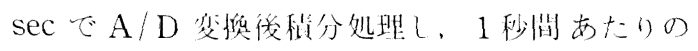
伯に換算した。

(2) 下㖽速的

デジタルレコーダに收錄したサホン・ビジト レーナーの侣号を, X-Yレュータ (DA8400,

WATANABE 社製）に5倍の倍率で再生した。 そして，各ストロークの最上点より下方へ $1 \mathrm{~mm}$ と3 mm 開口したときの閉口路抢よび開口路と, 最上点を通る矢状面との水平的距離をデジタル， ギメ（デジマチックキャリバ500-110型，三典社 製）を用いて测定した（図2）。

\section{III. 研究結果}

\section{1. 最大咬みしめ}

1) 総筋活動量

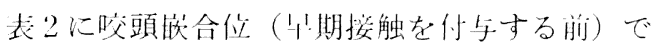
の最大咬又しめ時の各被騟者の筋活動最を示す。 総筋活動量は 593. 1 1,363. $5 \mu \mathrm{V} \cdot \mathrm{sec}$ 被験者

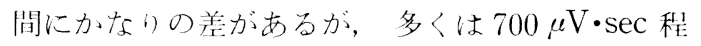
度であった。また各筋の活動量も同じよらに被䮖 芥間，および行によってかなりの伯の違いがあっ

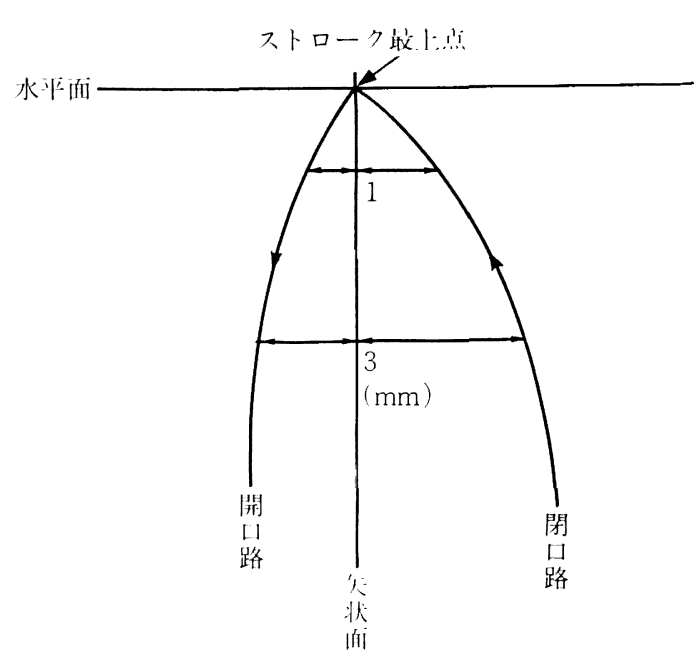

闵 2 ガム咀嚼時の下顎運動路と测定部位

た。

早期接触を付与した後, 各被験者とも総筋活動 星は減少したが, 早期接触の位置による一定の傾 向はみられなかった。

2) 活動比率

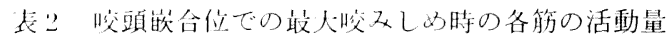

\begin{tabular}{|c|c|c|c|c|c|c|c|c|}
\hline \multirow{3}{*}{ 被 } & \multirow{3}{*}{ 易 省 } & \multirow{3}{*}{ 総筋活瑀旦 } & \multirow[b]{2}{*}{ 付 } & 各 & 筋 & 動 & 量 & \\
\hline & & & & 与 & 側 & 非 & 付 & 側 \\
\hline & & & $\mathrm{Mm}$ & $\mathrm{Ta}$ & $\mathrm{Tp}$ & $\mathrm{Mm}$ & $\mathrm{Ta}$ & $\mathrm{Tp}$ \\
\hline & A & $\begin{array}{r}781.5 \\
41.6\end{array}$ & $\begin{array}{r}200.2 \\
16.7\end{array}$ & $\begin{array}{r}78.7 \\
3.1\end{array}$ & $\begin{array}{r}113.1 \\
5.0\end{array}$ & $\begin{array}{r}189.7 \\
14.7\end{array}$ & $\begin{array}{r}71.9 \\
1.2\end{array}$ & $\begin{array}{r}127.9 \\
1.9\end{array}$ \\
\hline & $\mathrm{B}$ & $\begin{array}{r}835.5 \\
50.4\end{array}$ & $\begin{array}{r}164.8 \\
10.4\end{array}$ & $\begin{array}{r}148.2 \\
9.2\end{array}$ & $\begin{array}{r}143.7 \\
8.5\end{array}$ & $\begin{array}{r}144.3 \\
14.1\end{array}$ & $\begin{array}{r}110.9 \\
5.3\end{array}$ & $\begin{array}{r}123.6 \\
5.7\end{array}$ \\
\hline & $\mathrm{C}$ & $\begin{array}{r}607.2 \\
20.6\end{array}$ & $\begin{array}{r}104.3 \\
7.5\end{array}$ & $\begin{array}{r}99.1 \\
4.0\end{array}$ & $\begin{array}{r}113.1 \\
2.8\end{array}$ & $\begin{array}{r}149.9 \\
7.0\end{array}$ & $\begin{array}{r}58.4 \\
1.4\end{array}$ & $\begin{array}{r}82.2 \\
3.2\end{array}$ \\
\hline & $\mathrm{D}$ & $\begin{array}{r}593.1 \\
13.0\end{array}$ & $\begin{array}{r}84.9 \\
4.1\end{array}$ & $\begin{array}{r}110.3 \\
3.5\end{array}$ & $\begin{array}{r}96.9 \\
6.4\end{array}$ & $\begin{array}{r}66.8 \\
3.7\end{array}$ & $\begin{array}{r}88.5 \\
3.7\end{array}$ & $\begin{array}{r}145.7 \\
8.3\end{array}$ \\
\hline & $\mathrm{E}$ & $\begin{array}{r}1,363.5 \\
146.0\end{array}$ & $\begin{array}{r}305.7 \\
46.0\end{array}$ & $\begin{array}{r}196.9 \\
13.7\end{array}$ & $\begin{array}{r}236.1 \\
31.5\end{array}$ & $\begin{array}{r}249.5 \\
32.6\end{array}$ & $\begin{array}{r}180.6 \\
13.7\end{array}$ & $\begin{array}{r}194.7 \\
23.6\end{array}$ \\
\hline & $\mathrm{F}$ & $\begin{array}{r}851.4 \\
46.8\end{array}$ & $\begin{array}{r}170.7 \\
11.1\end{array}$ & $\begin{array}{r}192.8 \\
19.3\end{array}$ & $\begin{array}{l}86.6 \\
10.4\end{array}$ & $\begin{array}{r}106.1 \\
2.3\end{array}$ & $\begin{array}{r}207.3 \\
10.6\end{array}$ & $\begin{array}{l}87.9 \\
10.0\end{array}$ \\
\hline
\end{tabular}


最大咬又しめをさせたときの各筋の活動状況を 知るため, 各筋の筋活動量が 6 筋の総筋活動量に 占める比率を活動比率として, 百分率 $(\%)$ で求 めた。四 $3 \sim 5$ は代表的と思われる被験者 B,

$\mathrm{D}, \mathrm{E}$ の活動比率である。付与側之非付与側の各 3 筋の活動比率を比べると, 被験者Bの早期接触 が大臼雨部にある場合と被験者 $\mathrm{E}$ を除いて，付与 側のほうが非付与側に比べ大きくなった。

早期接触の位置による变化についてみると, 被 験者 A， B， Cでは早期接触が小四蔽部にある場 合の注うが大日電部にある場合に比べ，付与側 3

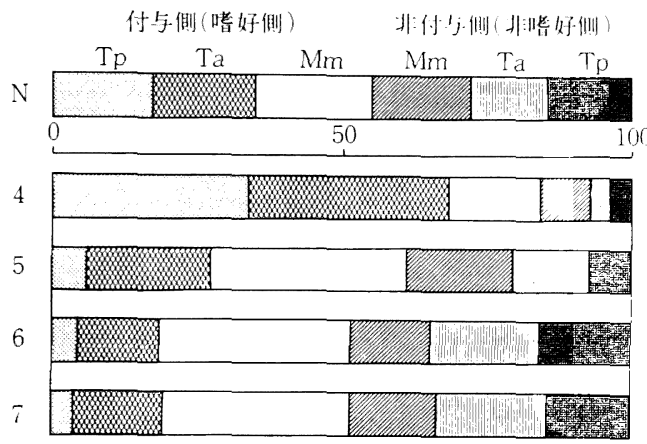

図 3 最大咬及しめ時の各筋の活動比率(被娩者 B) $\mathrm{N}$ : 咬頭嵌合位 4：第一小四歯付与. 5 : 第二小臼歯付与 6 : 第一大四歯付与 7 : 第二大臼歯付与

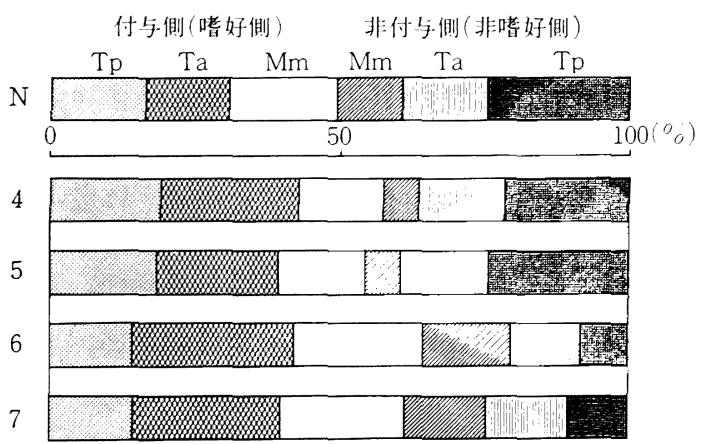

図 4 最大咬みしめ時の各笳の活動比率(被験者 D) $N$ : 咬頭嵌合位 4: 第一小臼歯付与 5 : 第二小臼歯付与 6 : 第一大且歯付与 7 : 第二大臼歯付与

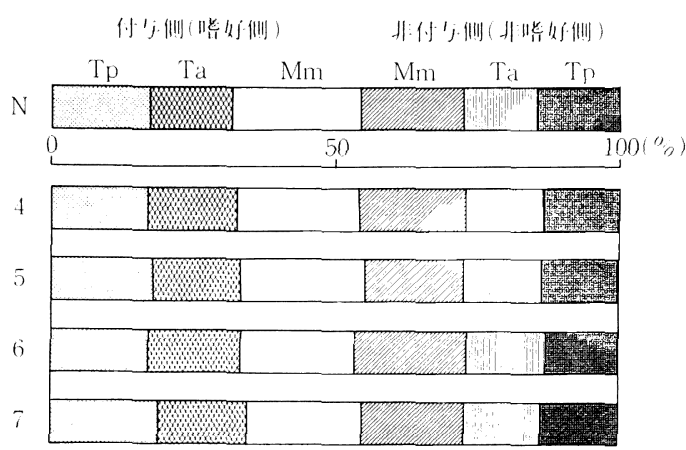

図 5 最大咬又しめ時の各筋の活動比率( 被験者 E)

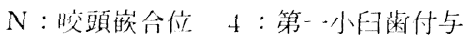
5: 第一小四糊村与 6 : 筝一个溥付与 7 : 第: 大下飠付与

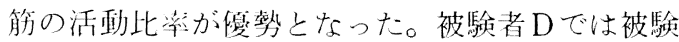
者Aらとは逆に，早期接触が大臼㐘部にある場合 のほうが付与側 3 筋の活動比率は優勢となった。 被験者 $\mathrm{E}, \mathrm{F}$ では早期接触の位罡に上る活動比率 の变化は少なく，一定の倾向はみら机なかった。

各筋について早期接触の位圆の違いに上る変化 をみると、両側の Tp で最も顕著であった。つま り, 付与側の $\mathrm{Tp}$ は早期接触が後方に移動するに 徒い活動比率は減少し, 非付与側の Tp は逆に増 加する被験者が多かった。 Taは $\mathrm{Tp}$ と似た傾向 を示すが変化は少なく, Mmは被験者によって種 種で一定の傾向は久られなかった。

3) IP 比

被験者間の筋活動量にはばらつきが大きい。し たがって最大咬多しめ時の筋活動を被験者相互間 で比較しょらとするには，寒測值そのままでは正 しく評価できない。そのため各筋ごとに咬頭嵌合 位 (IP) での最大咬みしめ時の筋活動量の平均值を 1.00 とし，それに対して早期接触を付与して最大 咬みしめさせたときの䈈活動量をとれに対する比 率で表し，これをIP 比とした35,36)。これによっ て各被験者, 各筋について筋活動の状況を比較㭥 讨することにした。被験者 $\mathrm{B}, \mathrm{D}, \mathrm{E} の$ 各筋の IP 比を図 6 〜 8 に示す。

(1) 付与側 


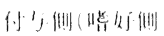

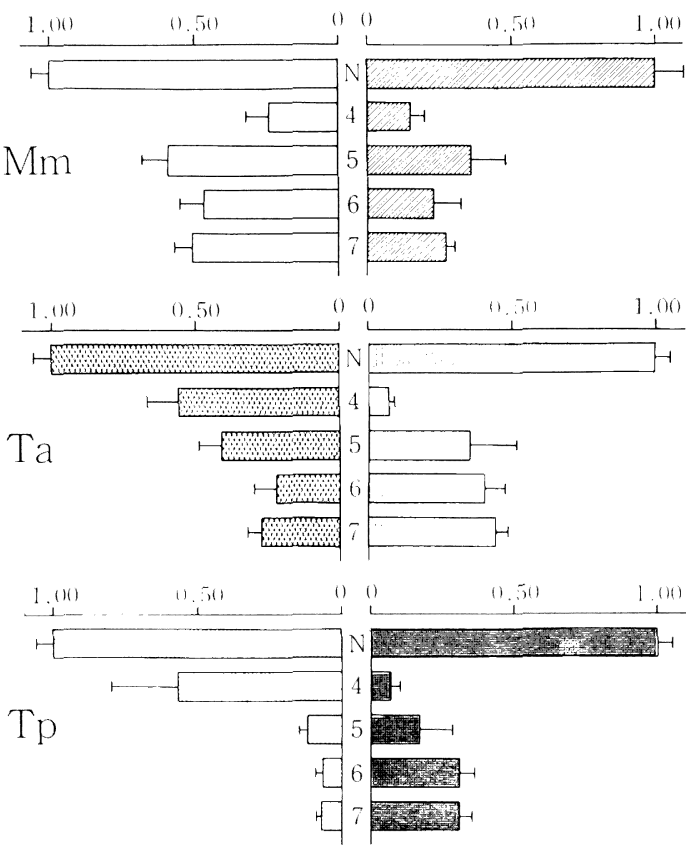

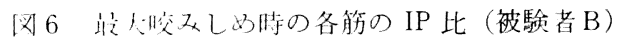

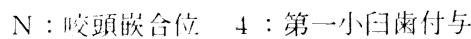

$$
\begin{aligned}
& 5 \text { : 第二小四歯付与 } \\
& \text { 6: 第一大巨四付与 } \\
& 7 \text { : 第一大田战付与 }
\end{aligned}
$$

早期接触の位置による各筋の IP 比の変化は, Tp で比較的一定の傾向がみられたが，Mm では 被娩者によって種々であった。

すなわち，Mmについては，被験者 $\mathrm{D} て ゙$ 早期接 触が後方に移動寸るに彷いIP 比が大きくなった

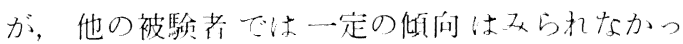
た。

Taについては，被験者 B，Cにおいて早期接 触が第一小四雨から第二大臼画に移動するに從い 小さくなったが，被験者Dでは逆の傾向を示し た。他の被娩者では一定の傾向はみられなかっ た。

Tp では，被駼者 B， C，Dで早期接触が後方 に移動するに佂い小さくなった。また，被験者 $\mathrm{E}$ たは活の倾问を示し，被䮖者Fではほとんど早期 掞触の位罚に上る美異はみられなかった。
付与.倒 (喈好倒)

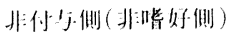

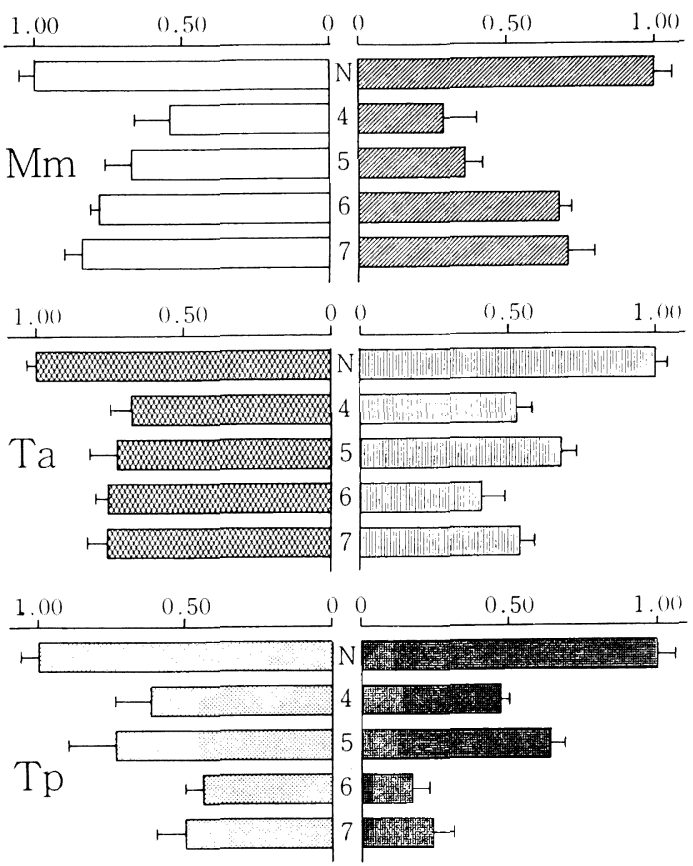

图 7 最大咬及しめ時の各筋の IP 比（被験者D） $\mathrm{N}$ ：狖頭嵌合位 4 : 第一小罒歯付与 5 : 第二小臼迷付与 6 : 第一大臼歯付与 7 : 第二大曰歯付与

(2) 非付与側

非付与側の場合，早期接触の位置による各筋の IP 比の変化は付与側之同様に Tp で一定の傾向 が認められたが，Mmではみられなかった。

Mmについては, 被験者 Dで早期接触が後方に 移動するに侹いIP 比は大きくなり，被験者 $\mathrm{E}$, $\mathrm{F}$ では早期接触が第一大臼歯にあるときに最も大 きくなった。

$\mathrm{Ta}$ では, 被験者 $\mathrm{A}, \mathrm{B}$ に掞いて早期接触が後

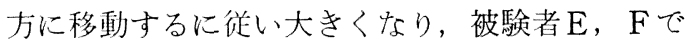
は早期接触が第一大四歯にあるときに最も大きく なった。

$\mathrm{Tp}$ では，被験者 $\mathrm{A} ， \mathrm{~B}, \mathrm{C}$ に扔いて早期接触 が第一小四歯にあるとき，IP 比は $0.07 〜 0.18$ と 極端に小さくなった。被験者 $\mathrm{A}, \mathrm{B}, \mathrm{F}$ では早期 接触が第一小罒歯から第二大臼歯に移動するに往 


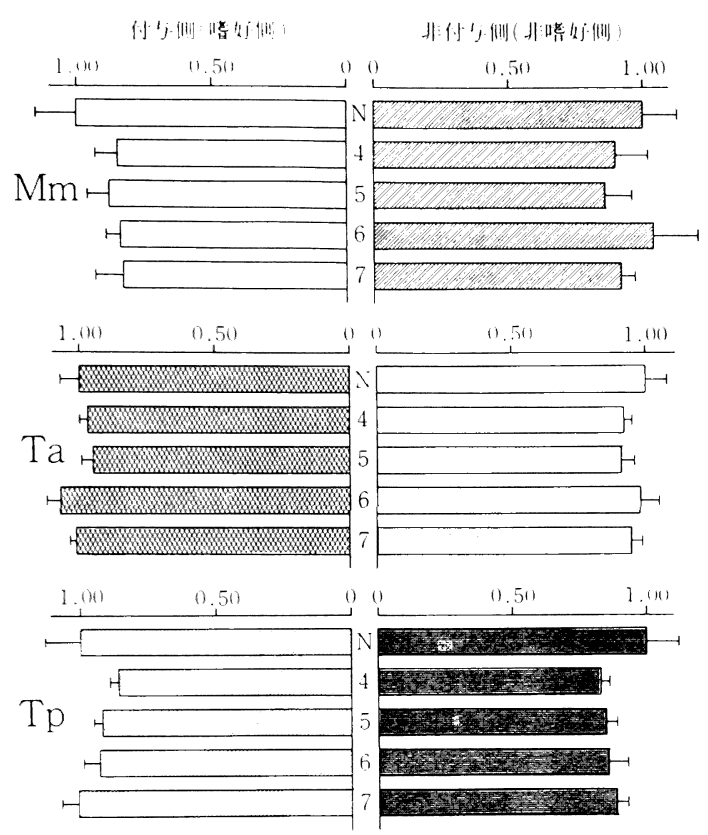

図 8 最大崚又しめ時の各筋の IP 比（被験者 $\mathrm{E}$ ) $\mathrm{N}$ : 咬頭嵌合位 4 : 第一小囦歯付与 5 : 第二小臼歯付与 6 : 第一大臼霜付与 7 : 第二大臼歯付与

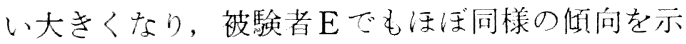
した。被験者 Cでは被験者 $\mathrm{A}, \mathrm{B}, \mathrm{F}$ と同様の傾 向を示すが早期接触が第一大目歯にあるときに最 も大きいIP 比を示した。しかし被験者Dでは， 逆に早期接触が大臼歯部よりも小妇戍部にあると きのほらが，IP比は大きくなった。

\section{2. ガ么咀嚼}

1）時 間

(1) 閉口相

(1) 付与側咀嚼

ガム咀嚼時の閉口相時間は，早期接触を付与す る前 (嗜好側咀嚼) は0.16〜0. 26秒であった。早 期接触付与後は0. 16〜0.30秒となり，やや延長す る傾向を示した。しかしその位置や被験者間で一 定の傾向は文られなかった。

(2) 非付与側咀嚼

閉口相時間は早期接触を付与する前（非啹好側
咀㗖）は0. 15〜0.24秒であった。早期接触付与後 は0.16〜0.28秒となり，やや近長する倾问を示し た。早期接触が第一小曰断から第二大印断に移動 するに促い，被験者 $\mathrm{A} ， \mathrm{~B}$ で延長する傾问がみら れるものの，他の被験者では一定の傾向は双られ なかった。

(2) 咬合相

\section{1) 付与側咀嚼 (図 9)}

早期接触付与前，咬合相時間は被験者 $\mathrm{E}$ を除い て0.16〜0. 19秒であった。早期接触打与後は0.11 〜0. 22秒となった。被験者 A， B，Eで早期接触 が第一小扫歯から第一大四霜に移動するに良い知 維したが，その他の被験者では汪とんど変化はな かった。

\section{2. 非付与側咀嚼（図10)}

早期接触付与前，咬合相時間は被験者 $\mathrm{E}$ を除い て0.14〜0. 20秒であった。早期接触付与㣪は0.10 〜0.21秒となった。被験者 B， Eでは早期接触が 第一大四齿にあるときに最年短くなった。特に被 験者 Bでは早期接触が第一大曰粈にあるときは 0.10秒に短縮した。他の被験者では特に一定の倾 问は又られなかった。

(3) 開口相

(1) 付与側咀唓

早期接触付与前，開口相時間は $0.17 \sim 0.25$ 秒で あった。早期接触付与後は $0.17 〜 0.27$ 秒となり, 延長するものと短縮するものがあった。また， て の位置や被験者間には一定の傾向は开られなかっ †。

\section{(2) 非付与側咀嚼}

早期接触付与前，開口相時間は0. 20〜0. 29秒で あった。早期接触付与後は0.17〜0. 28秒となり， 延長するものと短縮するものがあった。被験者 A， B，Cにおいて，早期接触が第二小囦歯にあ るときに開口相時間が最も短くなった。しかし全 被験者とも特に一定の傾向はなく，早期接触の位 置による変化は少なかった。

\section{2）筋活動}

早期接触を付与する前のガ么勗嚼時の統筋活 動量を表 3 に示す。嘫好側の咀嚼では閉口相で 


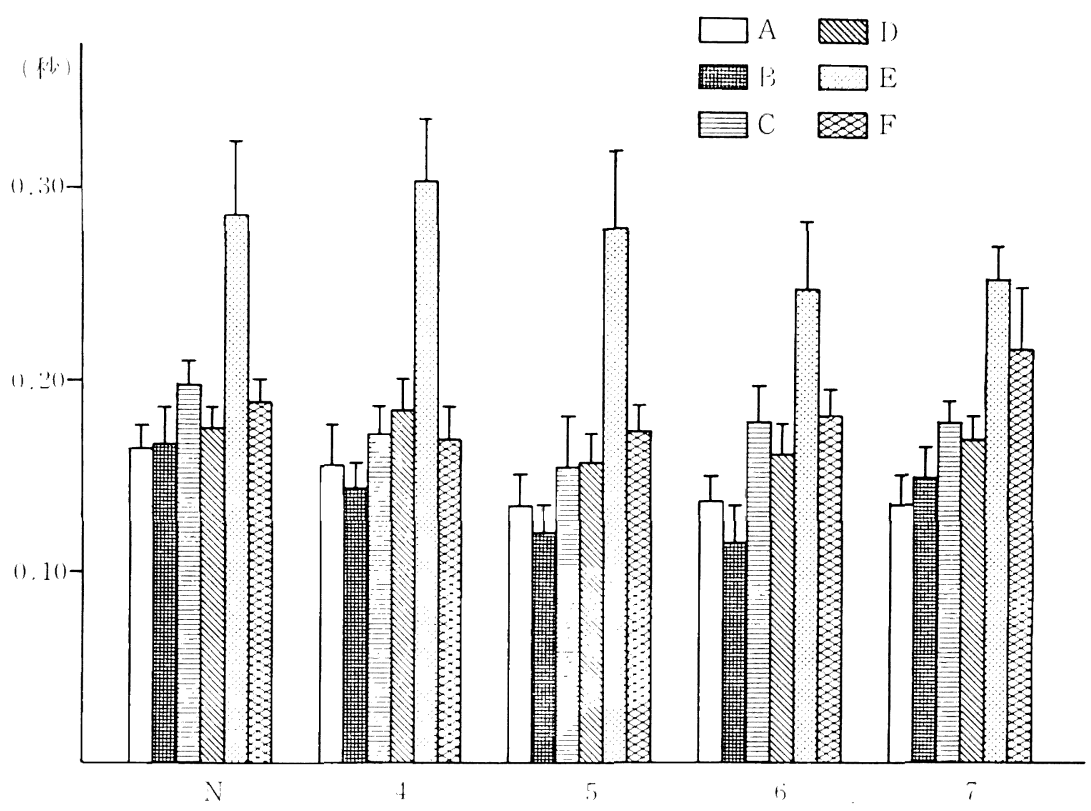

闵 9 付与側 (嘫好側) 咀嚼にお忛る各被験者の咬合相時間

$\mathrm{N}$ : 早期接触なし 4 ：第一小臼米付与 5 ：第二小臼歯付与 6 : 策一大四料付与 7 : 第二大四歯付与

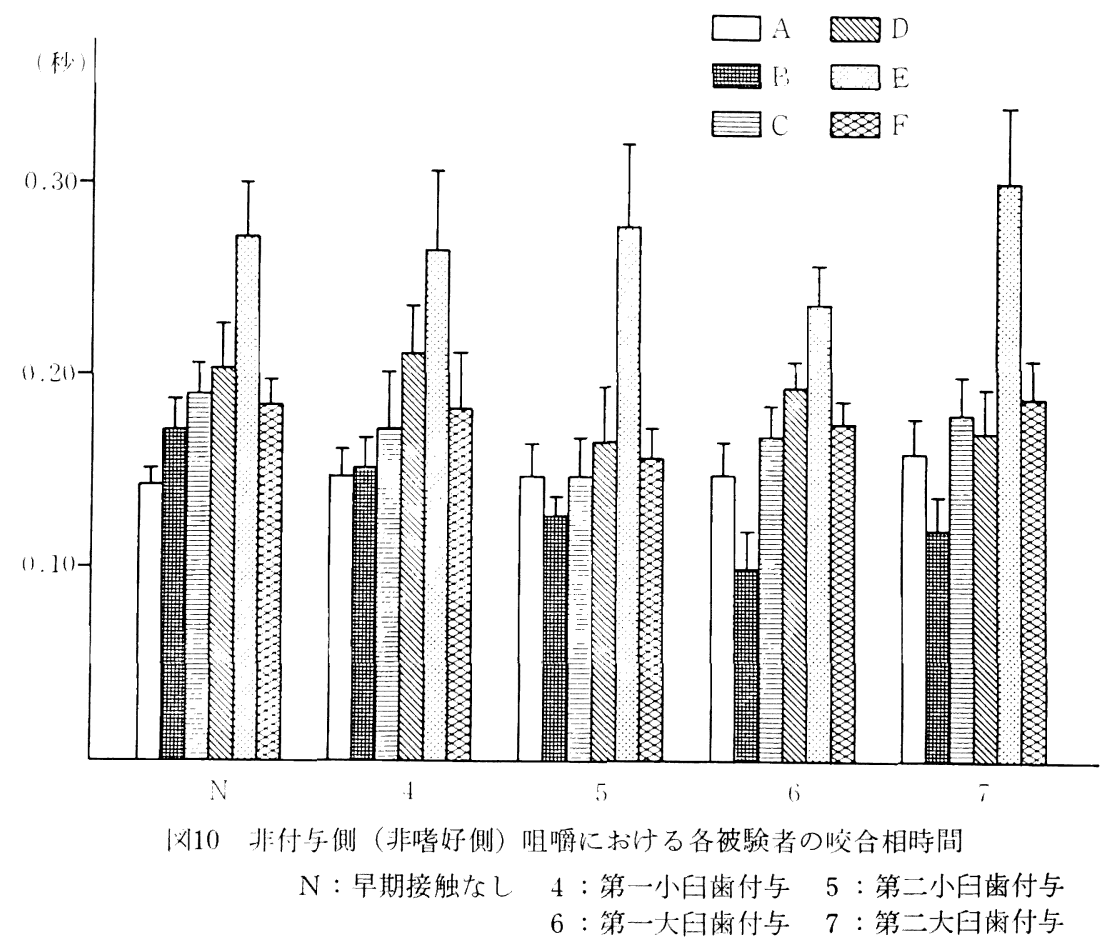




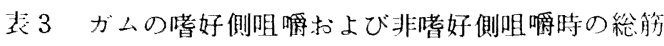
活動量

\begin{tabular}{|c|c|c|c|c|}
\hline & \multicolumn{2}{|c|}{ 㫮好側咀嚼 } & \multicolumn{2}{|c|}{ 非嗜好側咀嚼 } \\
\hline 被験者 & 閉口相 & 咬合相 & 閉口相 & 咬合相 \\
\hline$A$ & $\begin{array}{r}295.1 \\
24.5\end{array}$ & $\begin{array}{l}98.1 \\
10.0\end{array}$ & $\begin{array}{r}278.1 \\
25.8\end{array}$ & $\begin{array}{l}74.2 \\
13.8\end{array}$ \\
\hline B & $\begin{array}{r}139.4 \\
19.3\end{array}$ & $\begin{array}{r}74.9 \\
9.0\end{array}$ & $\begin{array}{r}210.2 \\
25.3\end{array}$ & $\begin{array}{r}74.9 \\
6.4\end{array}$ \\
\hline $\mathrm{C}$ & $\begin{array}{r}244.9 \\
21.2\end{array}$ & $\begin{array}{r}114.7 \\
13.5\end{array}$ & $\begin{array}{r}262.3 \\
22.2\end{array}$ & $\begin{array}{l}94.9 \\
13.8\end{array}$ \\
\hline $\mathrm{D}$ & $\begin{array}{r}358.3 \\
25.0\end{array}$ & $\begin{array}{r}135.3 \\
18.2\end{array}$ & $\begin{array}{r}328.3 \\
22.8\end{array}$ & $\begin{array}{r}158.9 \\
20.9\end{array}$ \\
\hline $\mathrm{E}$ & $\begin{array}{r}204.8 \\
35.7\end{array}$ & $\begin{array}{r}170.9 \\
30.6\end{array}$ & $\begin{array}{r}337.6 \\
23.8\end{array}$ & $\begin{array}{r}205.0 \\
31.8\end{array}$ \\
\hline $\mathrm{F}$ & $\begin{array}{r}397.2 \\
29.0\end{array}$ & $\begin{array}{r}173.2 \\
15.6\end{array}$ & $\begin{array}{r}374.2 \\
24.8\end{array}$ & $\begin{array}{r}124.8 \\
16.2\end{array}$ \\
\hline
\end{tabular}

上段：平均 $(" \mathrm{~V} \cdot \mathrm{sec})$ 下段：SD

139. 4 397. 2 «V・sec, 咬合相で74. 9 173. $2 \mu \mathrm{V}$ ・ sec だあり，非莻好側では閉口相で210. 2 374. 2 " $\mathrm{V} \cdot \mathrm{sec}$ ，咬合相厅74.2 2 205.0 $\mu \mathrm{V} \cdot \sec$ の活動量 だあった。最大咬みしめ時と同椂に被験者間, お よび閉口相，咬合相で総筋活動量は種々である。

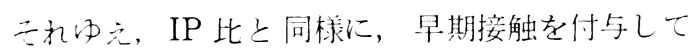
ないときの嗜好側, 非嗜好側, それぞれの咀嚼に お汁る各相, 各筋の活動量を 1.00 とし, 早期接触 を付与したときの各筋の活動量をとれに対する比 率で表した。

(1) 閉口相

1 付与側咀嚼（図11, 12)

被験者A，Bの結果を図11，12に示す。

早期接触付与後, ほとんどの被験者で各筋の活 動量は減少した。

付与側の Mm においては, 被験者Bで第二小 曰歯，第一大臼歯で減少する形を示したが，その 他の被験者では早期接触が後方に移動するに椾い 活動量は増加し, 被験者 $\mathrm{C}, \mathrm{D}, \mathrm{F}$ では第一大臼

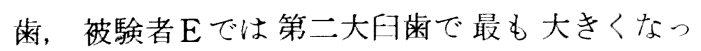
た。

付与側の Taにおいては, 被験者 $\mathrm{A}, \mathrm{D}, \mathrm{F}$ で

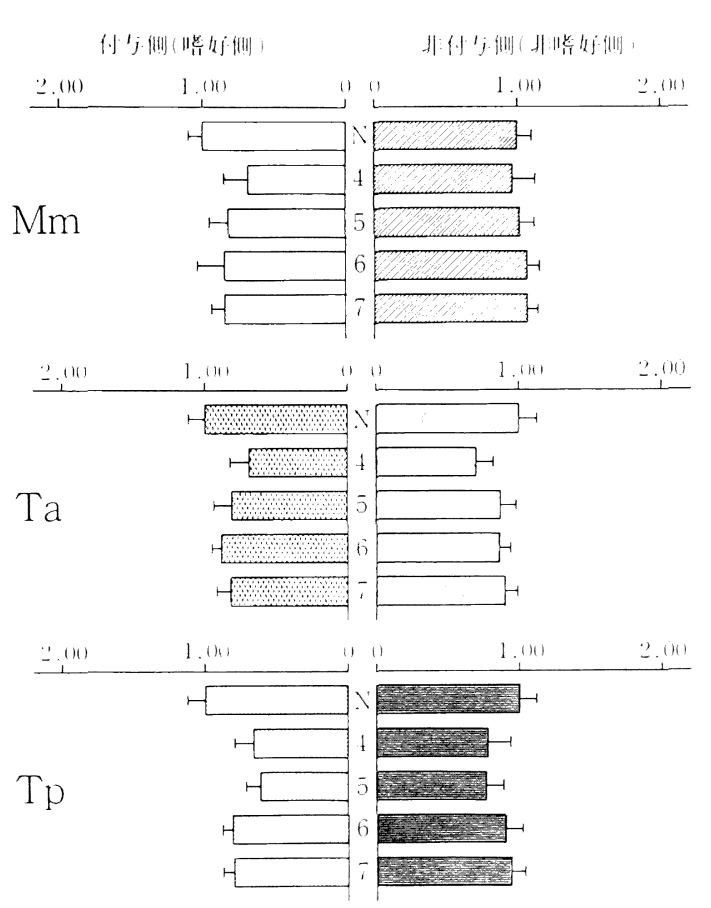

困11 付与側 (喏好側) 咀嚼の閉口相における各筋の 筋活動 (被験者 A)

$$
\begin{aligned}
& \text { N：早期接触なし } 4 \text { ：第一小臼嵙付与 } \\
& 5 \text { : 第二小臼歯付与 } \\
& 6 \text { : 第一大鼠落付与 }
\end{aligned}
$$

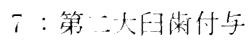

早期接触が第一小四断から第一大臼蔽に移動寸る に従い活動量は増加したが、被験者 B，Eだは逆 に減少した。

付与側の Tp においては, 被験者 $\mathrm{A}, \mathrm{D}, \mathrm{E}$, Fで早期接触が後方に移動するに往い活動量は増 加し, 被験者 $\mathrm{D}, \mathrm{F}$ では第一大臼歯で最も大きく なった。被験者 $\mathrm{E} て ゙ は$ 付与側の 3 筋とも早期接触 付与後, 活動量は増加した。

一方，非付与側について Mm では，被験者 B を除いて付与側と同樣，早期接触が後方に移動す

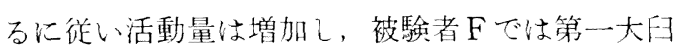
歯で最も大きくなった。また被験者 $\mathrm{D}, \mathrm{E}, \mathrm{F} て ゙$ は早期接触付与後のほらが活動量は大きくなっ た。

非付与側の Taにおいても被験者 B を除いて早 期接触が後方に移動するに従い増加し, 被験者 


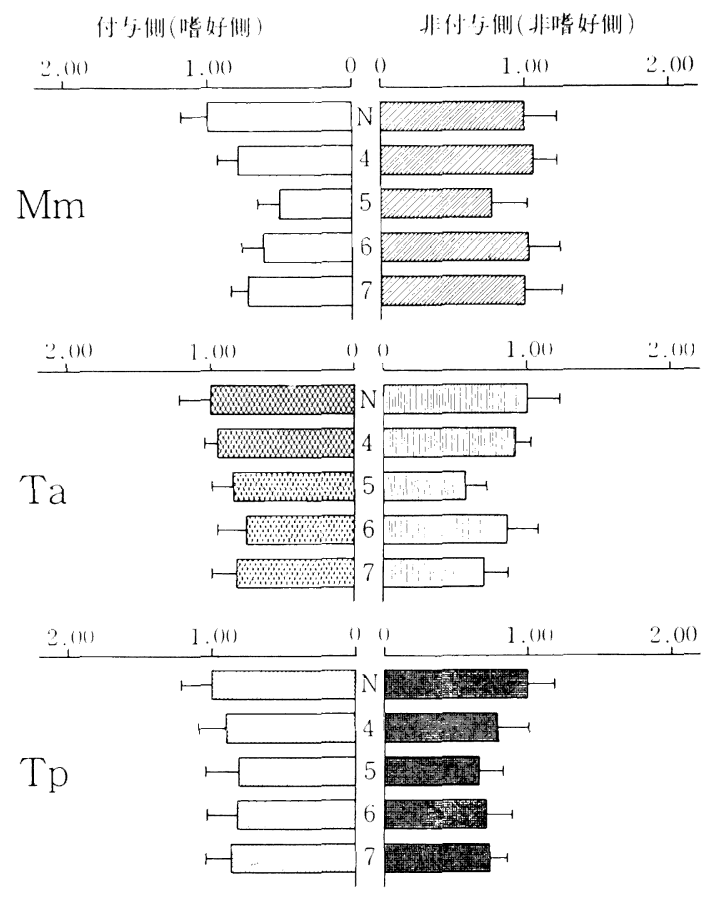

[为12 付与側 (嘫好側) 咀嚼の閆口相における各筋の 筋活動（被駼者 B)

$$
\begin{aligned}
& N \text { ：早期接触なし } 4 \text { ：第一小目橉付与 }
\end{aligned}
$$

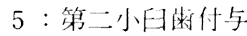

$$
\begin{aligned}
& \text { 6：第一大臼歯付与 } \\
& 7 \text { : 第二大旧歯付与 }
\end{aligned}
$$

C， D， Fでは第一大臼粈で最も大きくなった。

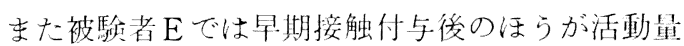
は大きくなった。

非付与側の Tpに扔いては非付与侧の Ta とほ ほ同じ傾向を示した。

(2) 非付与側咀嚼 (図13，14)

被験者 B，Fの結果を図13，14に示す。

付与側咀嘅と间梯に早期接触付与後, 各筋の活 動星は減少した。

付与側の $\mathrm{Mm}$ に扔いては, 被験者 $\mathrm{B}, \mathrm{F}$ で早 期接触が後方に移動するに従い活動量は減少し た。しかし他の被験者では早期接触の位置による 一定の傾向はみられなかった。

付与側の Taにおいては, 被駼者 $\mathrm{E}, \mathrm{F}$ で早期 接触が後方に移動するに従い活動量は増加した。 他の被驞者では早期接触の位置による一定の傾向

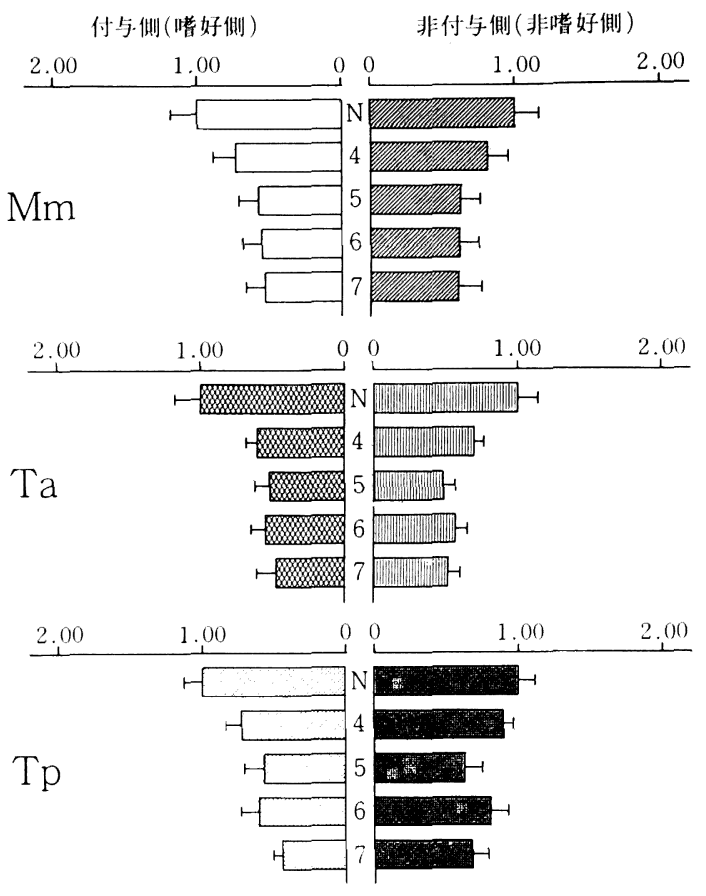

困13 非付与側（非嗜好側）咀嚼の閉口相における各 筋の筋活㲘（被験者 B)

$$
\begin{aligned}
& \mathrm{N} \text { ：早期接触なし } 4 \text { ：第一小臼歯付与 } \\
& 5 \text { : 第二小四歯付与 } \\
& 6 \text { : 第一大且歯付与 } \\
& 7 \text { : 第二大且歯付与 }
\end{aligned}
$$

はみられなかった。

付与側の Tp においては, 被験者 $\mathrm{A}, \mathrm{B}$ で早期 接触が後方に移動するに従い活動量は減少した。 しかし被験者 D， E， Fでは早期接触が後方に移 動するに従い活動量は増加し, 被験者 D, Eでは 早期接触が第一大臼歯にあるときに活動量は最も 大きくなった。

一方，非付与側について $\mathrm{Mm}$ では，被験者 B で早期接触が後方に移動するに従い活動量は減少

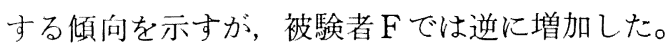
他の被験者では早期接触の位置による一定の傾向 はみられなかった。

非付与側の Ta においては, 早期接触の位置, 被験者間には一定の傾向はみられなかった。

非付与側の $\mathrm{Tp}$ に拈いては, 被験者 $\mathrm{A}$ で早期接 触が後方に移動するに従い活動量は減少したが, 


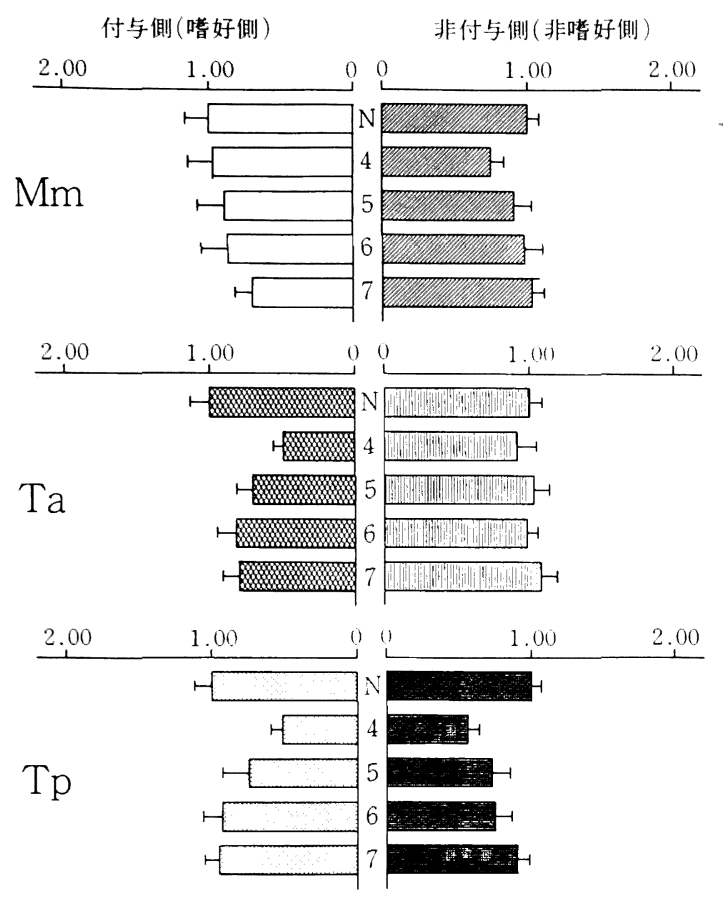

図14 非付与側（非嗜好側）咀嚼の閉口相における各 筋の筋活動 (被験者 F)

$$
\begin{array}{ll}
\mathrm{N} \text { : 早期接触なし } & 4 \text { : 第一小四歯付与 } \\
5 & \text { : 第二小臼歯付与 } \\
6 & \text { : 第一大臼歯付与 } \\
7 & \text { : 第二大臼歯付与 }
\end{array}
$$

皮験者 Fでは逆に増加した。他の被験者では早期 妾触の位置による一定の傾向は認められなかっ r。o

(2) 咬合相

(1) 付与側阻嚼 (図15, 16)

被験者 $\mathrm{A}, \mathrm{F}$ の結果を眓15，16に示す。

早期接触付与後, 各筋の活動量は減少する被虽 者が多かった。

付与側の $\mathrm{Mm}$ に拈いては被験者 $\mathrm{F}$ を除いて， 辞動量は早期接触が第二小四歯もしくは第一大田 隶にあるときに最も小さくなった。

付与側の Taに拉いても $\mathrm{Tm}$ と同じ傾向を示 し, 被験者 $\mathrm{F}$ を除いて活動量は第二小囦歯もしく よ第一大且畨で最も小さくなった。

付与側の $\mathrm{Tp}$ に扎いても被験者 $\mathrm{B}, \mathrm{C}, \mathrm{E}$ で $\mathrm{Mm}$ や $\mathrm{Ta}$ と同じ傾向を示した。

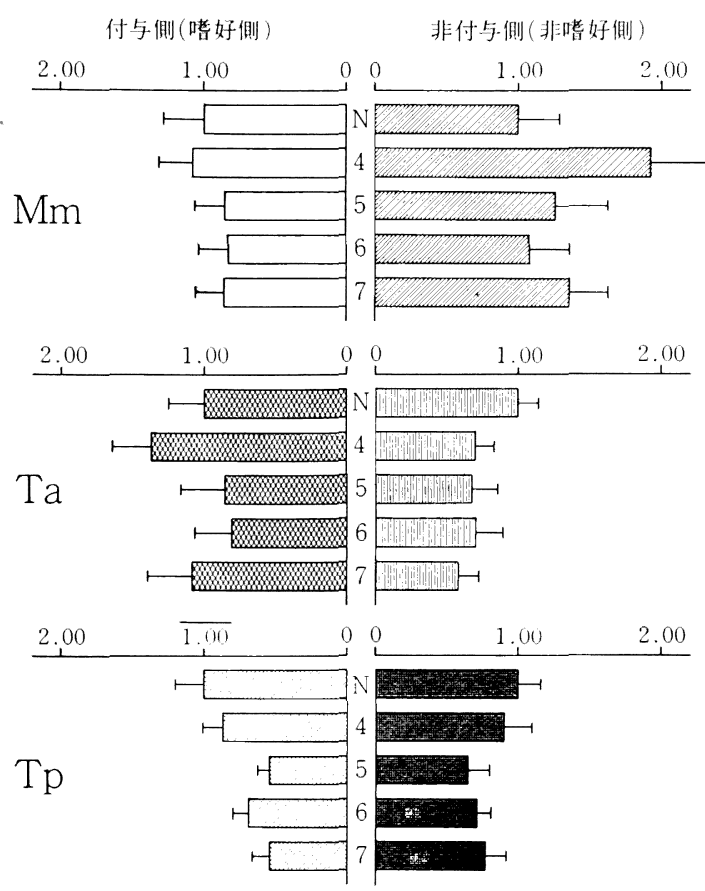

図15 付与側（㖺好側）咀嚼の咬合相における各筋の 筋活動（被験者 $\mathrm{A}$ )

$$
\begin{aligned}
& \text { N：早期接触なし } 4 \text { ：第一小臼迷付与 } \\
& 5 \text { ：第二小臼齿付与 } \\
& 6 \text { : 第一大日画付与 } \\
& 7 \text { : 第二大臼歯付与 }
\end{aligned}
$$

また，非付与側では， Mm においては被験者 A， B，Dで早期接触が第二小囦歯もしくは第一 大臼歯にあるときに活動量が最も小さくなった。 また被験者 $\mathrm{A}, \mathrm{D}, \mathrm{E}$ では早期接触付与後のほう が活動量は大きくなった。

非付与側の Ta に拈いては被験者 B， C, Eで 早期接触が第二小臼歯もしくは第一大䀠歯にある とさに最も小さくなった。

非付与側の $\mathrm{Tp}$ に打いては被験者 $\mathrm{A}, \mathrm{B}, \mathrm{E}$ で 早期接触が第二小四歯もしくは第一大四隶にある ときに最も小さくなった。

被験者 $\mathrm{F}$ はすべての筇において早期接触が第一 小罒歯から第一大四歯に移動するに従い活動量は 増加した。

(2) 非付与侧咀嚼 (図17, 18)

被験者 B，Fの結果を困17，18に示す。 


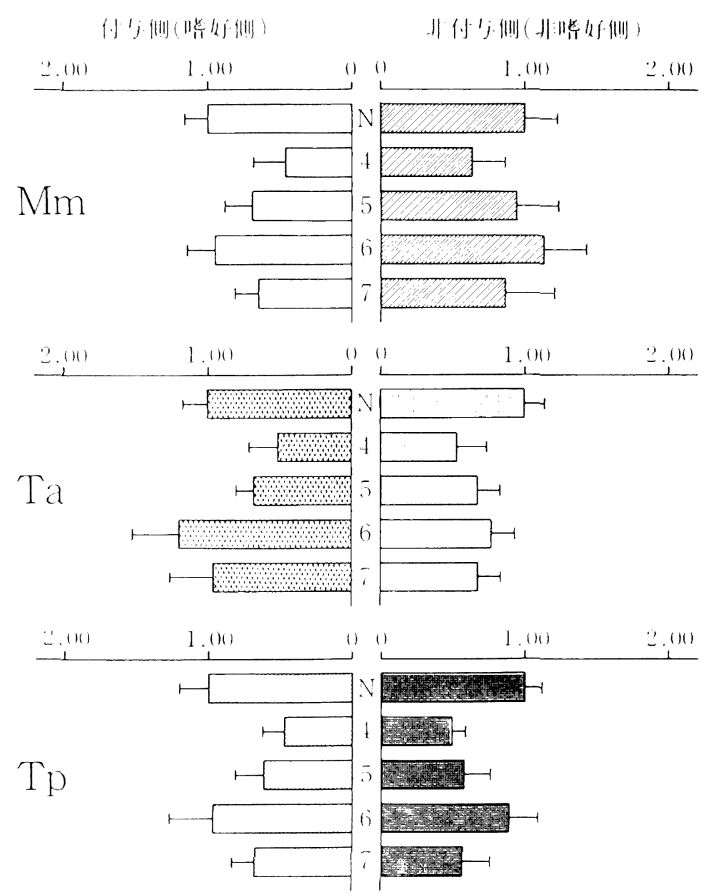

図16 付与側（嗜好側）咀嚼の咬合相における各筋の 筋活動 (被験者 F)

$$
\begin{aligned}
& \text { N：早期接触なし } 4 \text { ：第一小曰歯付与 } \\
& \text { 5: 第二小四歯付与 } \\
& 6 \text { : 第一大曰粰付与. } \\
& 7 \text { : 第二大曰齿付与 }
\end{aligned}
$$

早期接触付与後, 各筋の活動量は減少する被験 者が多かった。

付与側の $\mathrm{Mm}$ に括いては, 被験者 $\mathrm{A}, \mathrm{B}, \mathrm{C}$, $\mathrm{F}$ で早期接触が第一小臼歯から第一大田歯に移動

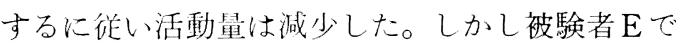
は，逆に早期接触が後方に移動するに従い活動量 は增加した。また被験者 $\mathrm{A}, \mathrm{D}$ では，早期接触村 与後のほうが活動量が大きくなる場合があった。

付与側の Ta においては, 被験者 Bで早期接触 が後方に移動するに従い活動量が減少する傾向を 示したが，被験者 $\mathrm{C} ， \mathrm{~F}$ では逆に活動量は増加し た。他の被験者では一定の傾向はなかった。

付与側の Tpに拈いては, 付与側の Ta とほほ 同じ結果となった。

一方, 非付与側では, Mmに捄いては被験者 $\mathrm{A}$, E， Fで早期接触が後方に移動するに從い活動量

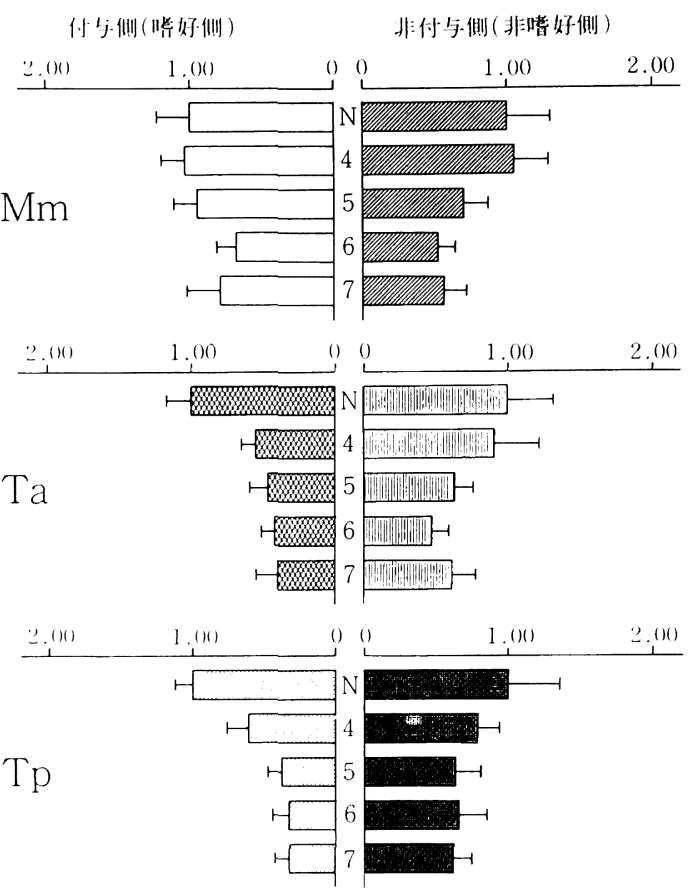

図17 非付与側（非嗜好側）咀嚼の咬合相における各 筋の筋活動（被験者 B )

$$
\begin{aligned}
& \mathrm{N} \text { ：早期接触なし } 4 \text { ：第一小臼歯付与 } \\
& 5 \text { : 第二小四歯付与 } \\
& 6 \text { : 第一大且歯付与 } \\
& 7 \text { : 第二大臼歯付与 }
\end{aligned}
$$

は增加したが，被験者Bでは逆に減少した。 非付与側の Ta においては, 被験者 B， C, F で早期接触が第二小四歯もしくは第一大田歯にあ るときに活動量は最も小さくなった。また被験者 A， Eでは早期接触が後方に移動するに従い活動 量は增加した。

非付与側の $\mathrm{Tp}$ に执いては, 被験者 Bで早期接 触が後方に移動するに従い活動量は減少し, 他の 被験者では一定の傾向はなかった。

3）下顎運動

(1) 閉口路

(1) 付与側咀嚼

被験者 $\mathrm{A} ， \mathrm{D}, \mathrm{E}$ の結果を図19に示す。

ガム咀嚼時の閉口路は早期接触の位置によって ほとんど変化がない場合が多かったが，被験者 A， B， C で早期接触が後方にあるほど, やや付 


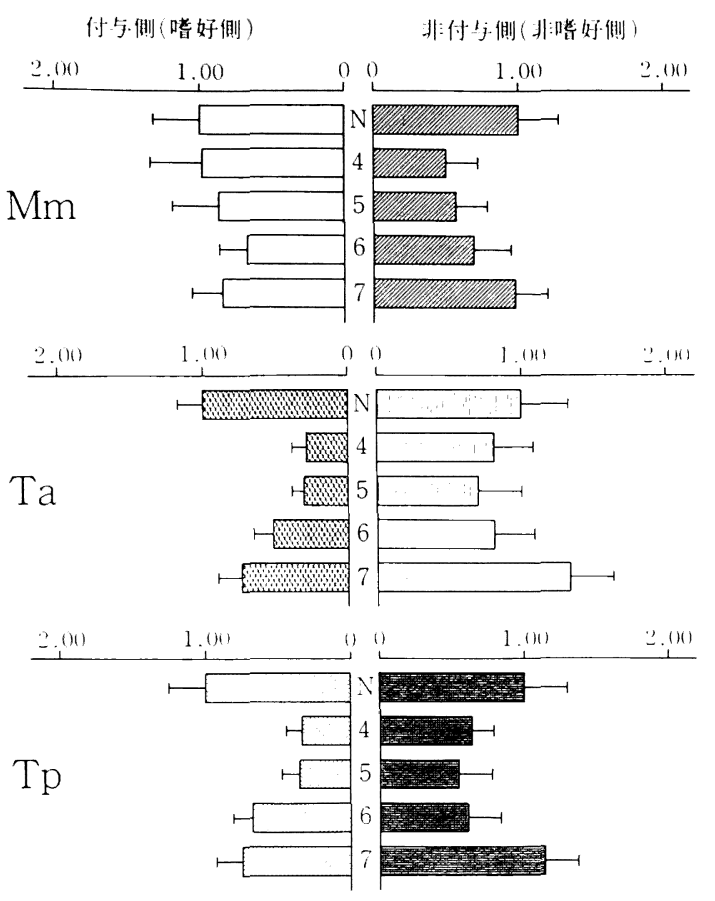

図18 非付与側（非嗜好側）咀嚼の咬合相における各 筋の筋活動（被験者 F)

$\mathrm{N}$ : 早期接触なし

$$
\begin{aligned}
& 4 \text { : 第一小囦歯付与 } \\
& 5 \text { : 第二小四歯付与 } \\
& 6 \text { : 第一大臼歯付与 } \\
& 7 \text { : 第二大曰歯付与 }
\end{aligned}
$$

与側に偏位する傾向がみられた。また被娩者Eで よ早期接触が第二小囦霜にあるときに，最も付与 則に偏位した。

(2) 非付与側咀嚼

被験者 $\mathrm{A} ， \mathrm{C}, \mathrm{F}$ の結果を眓20に示す。

閉口路には早期接触の位置によって著明な変化

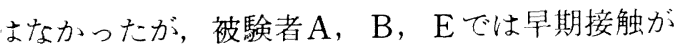
爱方にあるほど, やや非付与側に偏位する傾向が みられた。被験者Cでは早期接触が第二小臼歯に あるときに最も非付与側に偏位した。また, 被験

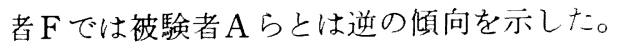

(2) 開口路

(1) 付与側咀嚼

被験者 $\mathrm{A} ， \mathrm{~B}, \mathrm{E}$ の結果を図21に示す。

開口路は被験者 $\mathrm{A}, \mathrm{C}, \mathrm{F}$ で早期接触が後方に あるほど付与側に偏位する傾向があった。被験者

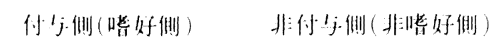

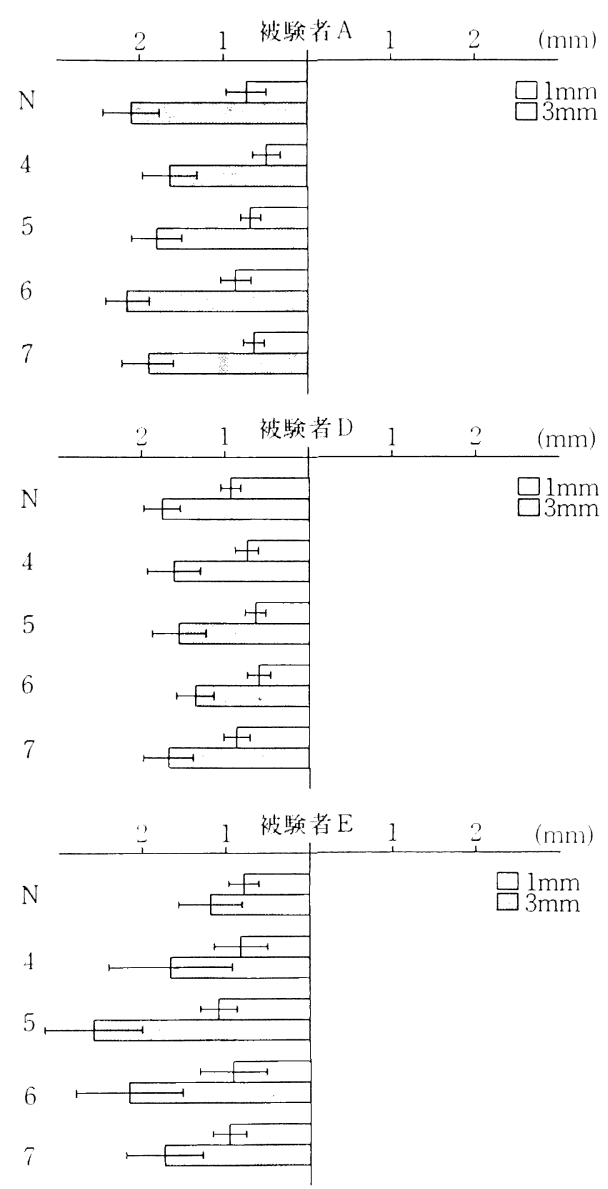

図19 付与側 (嘫好側) 咀嚼における閉口路

$\mathrm{N}$ ：早期接触なし 4 ：第一小围歯付与 5 : 第二小臼歯付与 6 : 第一大臼歯付与 7 : 第二大曰歯付与

$\mathrm{D}$ もとの傾向はあるものの, 著明な変化はなかっ た。被験者 B， Eでは早期接触の位置による運動 路の変化はほとんどなかった。

(2) 非付与側咀嚼

被験者 $\mathrm{A}, \mathrm{C}, \mathrm{E}$ の結果を図22に示す。

開口路は被験者 $\mathrm{A}, \mathrm{B}, \mathrm{C}, \mathrm{F}$ で早期接触が後 方にあるほど非付与側に偏位する傾向があった。 被験者 D, Eでは早期接触付与後ばらつきが大き くなり，一定の傾向はみられなかった。 

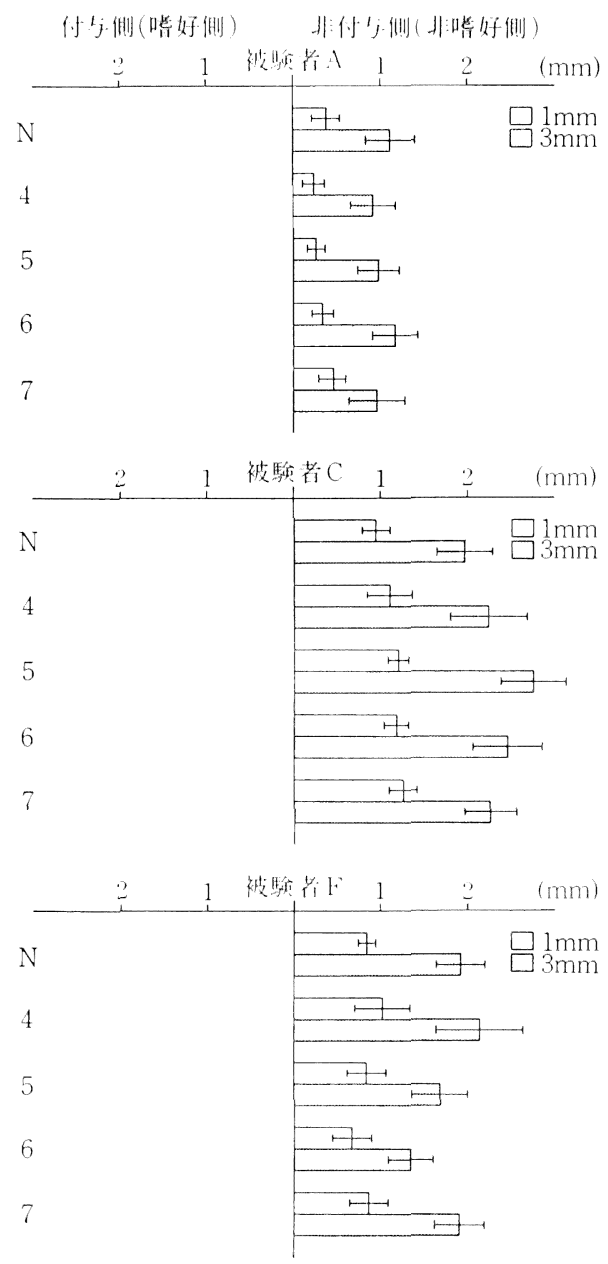

图20 非付与側（非嘴好側）咀嗳における䦥口路 $\mathrm{N}$ ：早期接触なし 4 ：第一小四歯付与 5 ：第二小臼崊付与 6 : 第一大囦歯付与 7 : 第二大日歯付与

\section{IV．総括ならびに考察}

早期接触が顎口腔系に及ほす影然については, 現在まで種々の㛟討がなされている。

Noble 5 ${ }^{32}$ は早期援触に上る幽の秒摇は可逆的 であるが，こ机によって二次的に引き起こされ るbruxismによる影響の注うが大きく，早期接触 のタイプと位沮が重要であると述べている。さら に小林 $5^{31)}$ は早期接触が内分泌系に影響を与克, 情動ストレスを惹起させることを報告している。

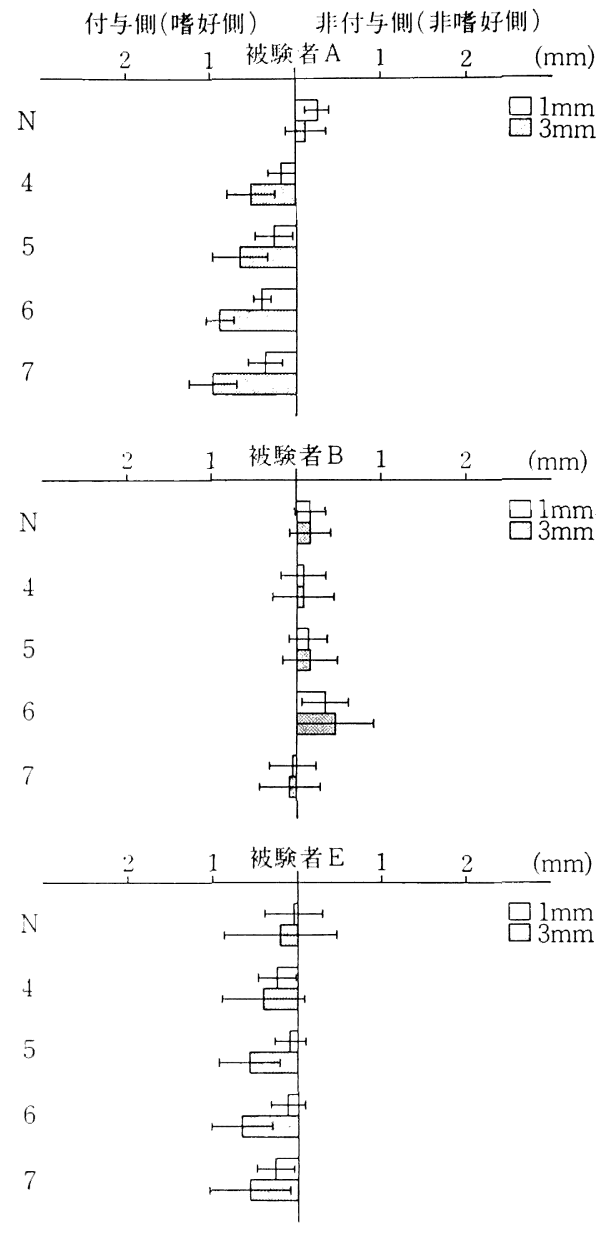

図21付与側 (嗜好側) 咀嚼における開口路

$\mathrm{N}$ : 早期接触なし 4 : 第一小目歯付与

5 : 第二小曰斗付与

6 : 第一大臼歯付与

7 : 第二大臼歯付与

このように早期接触は顎機能の異常を引き起こ す因子として涊められている37)が，本研究はその 位置によって顎口腔系へ及洔寸影響がどのように 異なるのかを明らかにする目的で，咀嚼嗜好側の 下顎第一小罒歯から第二大曰歯に実験的早期接触 を与え，筋活動，下顎運動との関係を検討したも のである。

\section{1. 研究方法}

1）被験者

本研究では実験的に早期接触を与光，それが㗁 


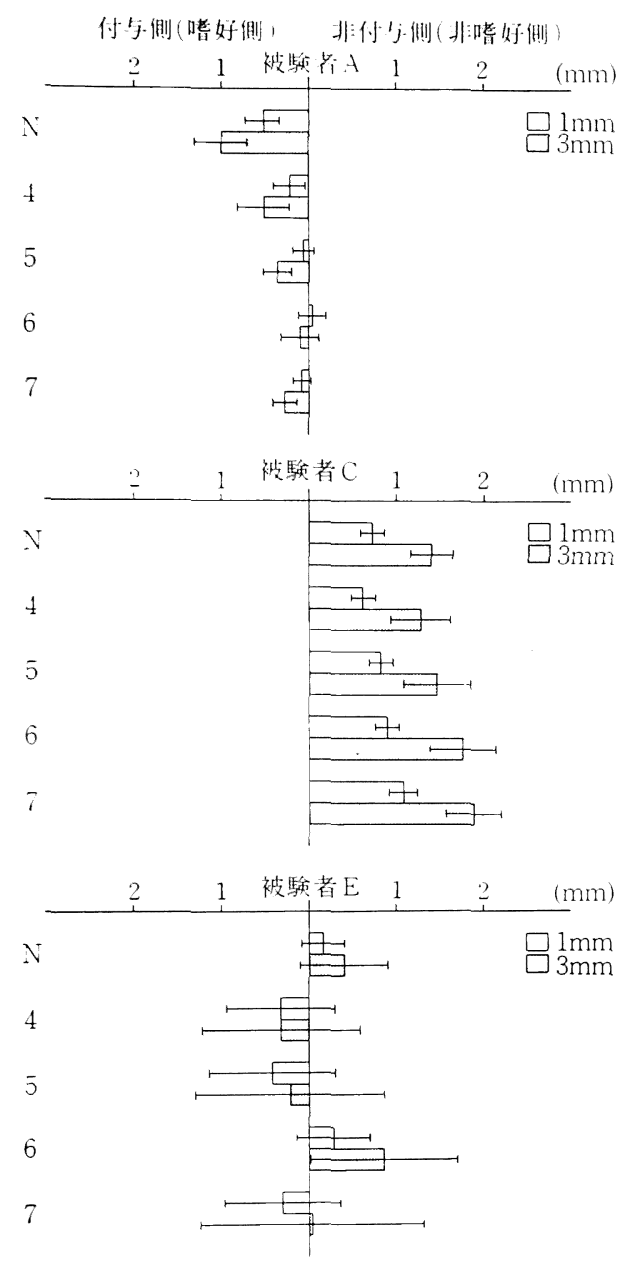

図22 非付与側（非喏好側）咀嚼における開口路

$\mathrm{N}$ ：早期接触なし 4 ：第一小曰齿付与 5 : 第二小臼歯付与 6 : 第一大白歯付与 7 : 第二大臼歯付与

口腔系にどのような影響を与えるのかを調べるこ ととした。そのため被験者には歯, 歯根膜, 顎関 節，咀嚼筋などに自覚的および他覚的に異常が認 められない，いわゆる個性正常咬合を有するもの を対象とした。また被験者はできるだけ口腔内に 根管処置や歯冠修復処置を行って扣らず，咬頭嵌 合位では少なくとも第一小臼歯から第二大臼齿ま でに嵌合があるものを条件とした。

2) 早期接触装置

実験的に早期接触を付与して顎口腔系への影響
を調べた報告は多いが，その中で用いられている 早期接触の種類や程度はさまざまである。早期接 触装置の種類としては環状のもの12,16,17,21)，イン $レ-7,10,19,22,28,31) ， \quad ン レ-8,9,13,15,25)$ ， クラウ ン11,27)，ブリッジ3)，クラスプ6)，アマルガム充 填 ${ }^{20,23,26) ， コ ン ホ ゚ シ ゙ ッ ト レ シ ゙ ン 24) に よ る も の な と ゙ ~}$ がある。本研究では歯質の削除をせず，また側方 滑走運動時にはできるだけ接触させないようにす るため, 早期接触装置は下顎の田歯の舌側咬頭を 覆うアンレータイプとした。

実験的に付与寸る早期接触の程度としては45 $500 \mu \mathrm{m}$ の報告が多い。坂東 ${ }^{38)}$ は歯周 組織に 外傷性病変を起こすことなく適応可能なのは 100 $\mu \mathrm{m}$ 以下であると述べている。また，田中11)は早 期接触を与えてもその程度が $100 \mu \mathrm{m}$ のときは付 与 1 日後には障害された咀嚼機能は急速に回復す ると述べている。

予備実験で被験者に $50 \mu \mathrm{m}, 100 \mu \mathrm{m}, 150 \mu \mathrm{m}$ の早期接触を付与したところ, 被験者は50 $\mu \mathrm{m}$ で は付与直後に適応して感知しなくなり，また 150 $\mu \mathrm{m}$ ではかなり高く感じると訴えた。100 $\mu \mathrm{m}$ で は, 被験者は付与直後高く感じるが, そのまま放 置すると3〜4 日ほどで注とんど高いと感じなく なった。

そこで, 本研究で与兄る早期接触の程度は被験 者が付与後には高いと感じるが，適応する可能性 の限界と考穴られる100 的とした。

早期接触を付与する歯としては第一大臼歯が多 いが 5 11, 15, 18, 20 23, 25 28,31), 複数荬に付与した報 告として, 歯列内で近遠心的2, 16, 25, 29), 上下的9), 近遠心上下的 ${ }^{13)}$ に与六たものがある。また 1 歯に 異なるタイプの早期接触を与えたもの17, 19,21)など もある。しかし，咬合支持域である第一小臼歯か ら第二大曰歯の各歯に早期接触を設けてその顎口 腔系への影響を調べた研究はみあたらない。

3）筋活動の測定と分析方法

咬筋はその活動量と咬合力との相関が高々39), 咀㗖運動の prime mover の役制を担っており, 側頭筋は下顎の位置づけをする40)とともに，咬合 干渉に対しては他のどの咀嚼筋よりも敏感であ 
る411 と考无られている。また顎機能異常患者で咬 合異常が局所的因了として関与していたもののら 七, 呚頭崖合位に罢常がある群では, 咬頭嵌合位 以外の艾合位での断年接触の異常がある群に比

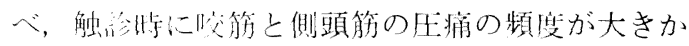
ったとの跟兵がある1)。そのため，本研究では咬 頭嵌合位に求ける早期接触の顎口腔系への影響を 検討するら学で筋としては，咬筋と側頭筋を対象 にすることにした。

筋活動の分所方法としては, 積分処理, 周波数 解析, サイレントピリオドの測定, 筋放電時間と 穴の間隔の测定などさまざまな方法がある。これ らの分析方法は研究の目的や方法によって使い分 けられている。作研究では筋活動を定量的にとら 兑，比較㛟封寸る日的からその有効性に一定の評 価が得られている積分值を筋活剩の指摽として用 いた。

\section{4）下唨遇動の測分:}

下顎運動の測定方法として，收近ではLED受

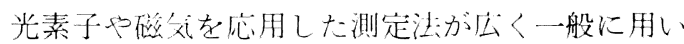
られている。+ホン・ビジトレーナーは LED 受 光素子を使用した装置で，口唇の完全閉鎖ができ ないことや三次元同時観察ができないといった久 点は亦るものの，比較的精度が高くX-Yレコー ダに各ストロークが再現でき，筇活動との同時記

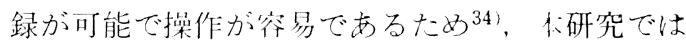
この装㯰を使用した。

下顎連動路の位罚的変化や各ストロークの形態 变化を娭璟寸る基準点としては中心咬合位が多く 用いられている42)が，本研究では中心咬合位で早 期接触を与えているため基準点としてこれを用い ることはできない。それゆえ各ストロークの最上 点を禁準点之し，その下方 $1 \mathrm{~mm}$ と $3 \mathrm{~mm}$ 開口時 の閉口路と開口路の水平的な位置の变化を調べる ことにした。

カム咀嚼で文られる運動路はいろいろな形を描 いたが，各ストロークの最上点は一致している場 合が注とんどであった。なお，早期接触を付与す ることによって生じる翼慣的閉口位の変化は，表 4のよらである。
表 4 早期接触付与後の習慣的閉口位の変位量

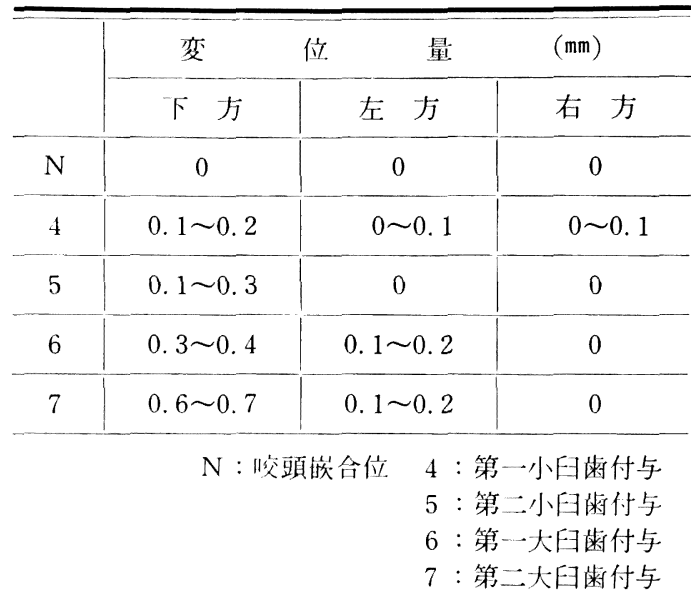

\section{2. 研究結果}

1）最大院々しめ

收大略又しいは嘰能的な動作ではないが比較的 持現性が高く43)，閉口筋の等尺性収縮動作の典型 として筋活動の測定項目にしばしば用いられてい る。

咬頭摸合位で最大咬质しめさせたときの総筋活 動昷をみると，被験者によってばらつきが大きく 各個人によって発揮できる筋活動量にはかなりの 差があることがわかる。また総筋活動量には早期 接触の位置の違いによる一定の変化傾向はみられ なかった。

礒39はスプリント上の片側の犬粜部，小臼断 部，大曰歯部で咬合力計を介在させ最大咬及しめ を行わせたところ，小目画部と大臼齿部では左有 の総筋活動量 $(\mathrm{Mm}, \mathrm{Ta}, \mathrm{Tp})$ には違いはなかっ たと述べている。また小笠原 ${ }^{44)}$ もプリント上で 第一小曰歯と第二大曰霜に支持点を設けて最大咬 みしめを行わせたところ，支持点の数と位置が前 後的に変化して子総筋活動量には一定の变化傾向 はみられなかったと報告している。いずれもスブ リントを使用しているものの本研究と一致した結 果を得ている。つまり, 本研究結果からみると早 期接触の位圈の違いによる最大咬みしめ時の総筋 活動量の变化には, 冬歯の咬合力支持能力の違い は直接的には影響していないようである。 
筋の活動比率をみると，早期接触を付与した後 では付与側の活動比率が大きくなる場合が多く， それは早期接触が大日歯部にある場合よりも小国 歯部にある場合の流うが著明なのが 6 例中 3 例あ った。これは非付与側で Tp の活動量が少ないこ とに関係している。

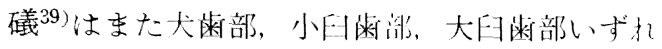
の部位においても咬合力計を咬ませた側の $\mathrm{Mm}$,

Ta，Tpの活動量が大きかったと報告している。 また，Bakke ら ${ }^{18)}$ は第一大囦に50〜200 早期接触を与え最大咬みしめを行わせたところ， 早期接触の程度が $50 \mu \mathrm{m}$ と $100 \mu \mathrm{m}$ で江付与側の 筋活動量は付与していないときよりも大きくな り, それ以上早期接触の程度が増すと付与してい ないときの值に近づくと報告している。さらに早 期接触付与側の筋活動のほうが非付与側の筋活動 よりも大きくなったことを認めており，ての原因 レして, 付与側の筋の muscle spindle の求心性 入力の增强をあげている。

IP 比については，早期接触を付与したのちの 各筋の IP 比は1を下まわる場合がほとんどであ り, 被験者 $\mathrm{E} の$ 早期接触が第一大四歯にあるとき にのみ 1 を越えた。Sheikholeslam ら ${ }^{23)}$ は右側 上顎第一大曰歯に $500 \mu \mathrm{m}$ の早期接触を与兄習慣 的閉口位で最大咬みしめを行わせると, 左右の $\mathrm{Mm}, \mathrm{Ta}, \mathrm{Tp}$ のすべての筋の活動量は減少した と述べている。その原因として，齿根膜からの negative feed-back, 歯の接触点数の減少, 咬合 力の作用方向の変化, 顆頭の移動, 精神的要因を あげている。Bakke らはまたその報告の中で早 期接触を付与した後, 付与側の筋の活動量が付与 前に比べ大きくなったとしているが，本研究結果 やSheikholeslam らの報告とは異なっている。 これは本研究や Sheikholeslam らの研究の早期 接触がアンレーやアマルガム小球による点状接触 であるのに対し， Bakke らはストリップスを用 いており，接触状態が異なっていたためかと推測 される。

咬合状態の変化には咬筋よりも側頭筋のほうが 鋭敏に応答するという報告は多い2,8, 10, 12, 18,24)。
早期接触の位置による各筋の IP 比の变化を又る と、特に Tp において比較的顕著であった。すな わた，付与側の Tp では早期接触が後方に移動す るに往いIP 比が小さくなるものが 6 例中 3 例あ り，大きくなるものが 1 例，一定の傾向を示さな いものが2例であった。非付与側の Tp は早期接 触が後方に移動するに從いIP 比は大きくなるも のが 6 例中 4 例, 第一大四棦までは大きくなるが 第二大日歯で小さくなるものが 1 例あった。 $\mathrm{Ta}$ は Tp と泳同じ傾向を示すものの Mm では位 吅による影響は一定ではなかった。

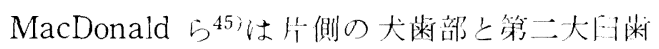
激でレジンブロックを介して最大咬みしめを行わ せたところ，同側の側頭筋の活動が犬状部よりも 第二大阳歯蔀で大きかったと報告しており，本研 究でも同じ結果が認められるものがあった。橋 太-46)は片側小臼糊でビニール線を介して最大唤 スしめを行わせると，対側の Tp の活動は汪とん どなかったと述べて扣り、こ执は本研究結果でも 6 例中 3 例に涊められた。一方，西山ら ${ }^{29}$ は片側 犬歯，第二小四歯，第二大四蔽に早期接触を与号 最大咬又しめを行わせたところ非付与側の筋の活 動量が減少し, さらに早期接触が後方に移動する に彷い非付与側の咬筋の活動量は減少し側頭笳は 增大したと報告しているが，この側頭筋の活動状 沉は本研究結果と一致している。また礒39) も支拈 点が後方にあるほうが対側の Ta, Tp の活動㫣は 大きくなると述べている。

2) 力八咀嚼

(1) $11:$ :

早期接触の位置の違いに対して閉山相時間には 全被験者を通じて一定の変化傾向はなかった。し かし, 非付与側咀㗖において早期接触が後方に移 動するに従い閉口相時間が延長するものがあっ た。咬合相時間は付与側において，早期接触が小 曰歯部よりも大四萰部にあるときのほうが短くな り，特に第一大四湈にあるときに最も短くなっ た。開口相時間はばらつきが大きく，早期接触の 位置に上る一定した倾何は又られなかった。

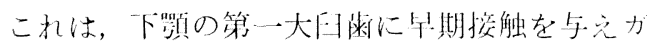


公咀嚼を行加せた結果, 閉口相時間は延長し, 咬 合相時問は短繀，閒口相時間は延長するものと短 縮するものとがあったとする林の報告19)とほぽ一 致している。

また顎関節症患者では，正常者と比較して閉口 相時間扮よび開口相時間は長く，咬合相時間は短 かったとの報告47)もある。

つまり早期接触を付与した被験者の咀嚼の時間 的様相には一定の傾向はないが，中には顎機能異 常者と似たところがあり ${ }^{19)}$ ，このことは早期接触 が筋神経機構に障害的に作用する可能性をらかが わせるものである。

(2) 筋活動

ガム咀緭時の筋活動は早期接触を付与した後減 少するものが多かったが，怆増大寸るものも あった。これに関して，大臼粎に早期接触を付与 しピーナッツ咀嚼を行わせたところ咀嚼筋の活動 は抑制され，それは特に早期接触を付与した側で 著しく抑制されたとの報告つや，下顎第一大臼歯 に早期接触を付与しガム咀嚼を行わせたところ， 非付与側の側頭筋の活動量が付与前上りも增加し たとの報告9) ある。また，羽田ら ${ }^{15)}$ は早期接触 付与後，筋活動には抑制タイフと非抑制タイブと があり，非抑制タイブを示すものは咀嚼経路の変 化が関係しているのであろらと推論している。

しかし, 本研究で咀嚼筋の活動蛏が減少したこ とについては，早期接触を付与した歯に過剩な力 が加わらない上らに防御反応が働いたためではな

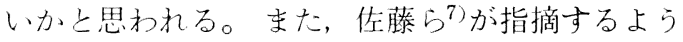
に早期接触が口腔内に新たに生じたために，被験 者が意識的に咬み方を変えた可能性も否定できな い。

一方，咀嚼笳の活動が増大した場合について は，早期接触が存在すると $\gamma$ 系を介する反射が起 こり，無意識のらちに障害のある個所で歯をすり 合わせたり咬みしめたりしてこれを除去しようと することがいわれている年が，そうした 与があって通常を越える大きな筋活動量が記録さ れたのかもしれない。

早期接触の位崖による影愁についてみると，ま
ず付与側咀畄の閉口相では付与側の筋は被験者 B を除いて早期接触が後方に移動するに従い筋活動 足は増大し，第一大臼歯で最大になるものと第二 大臼粎で最大になるものとがあった。非付与側の 筋に执いても付与側とほぼ同じであった。ついで 付与側咀嚼の咬合相では, 早期接触が第一大臼歯 にある場合に筋活動量が最小となる被験者が多か った。非付与側咀嚼では閉口相抢よび咬合相とも 筋活動には早期接触の位置による一定の変化傾向 は認められなかった。

付与側咀嚼時の閉口相で早期接触が後方にある ほうが筋活動量が大きくなったことについては, 各菌の支持能力の違い, 咬合力の 調節機構の 関 与49)が考兄られる。つまり，前方にある小臼歯は 単根歯で強い咬合力を受けるには不利であるた め，小臼歯部には過剩な力が加わらぬよらに調節 機構が強く働き，相対的に大臼歯部で活動量が大 きくなったのではないかと考えられる。

一方，早期接触が後方に移動するに従い付与側 咀嚼で咬合相の筋活動量が減少したことについて は次のよらに考兄られる。通常硬い食物を咀嚼す るときは，咬合相の側方運動量が大きくなり，か つこの時期に一致して筋活動量が大きくなること が認められている50)。ここで運動路をみると，早 期接触が後方に移動するに良い開口路はより咀嚼 側に偏位しており，対側への側方運動量が小さく なり臼磨運動がしにくい状態がうかがわれる。つ まり十分な咀嚼力が発揮できず筋活動量が減少し たものと思われる。

一方，非付与側咀嚼では閍口相，咬合相とも筋 活動にははっきりした一定の変化傾向はなかっ た。咀嚼時に作業側と平衡側にかかる咬合力を比 較すると, 平衡側のほうが小さいことが知られて (る ${ }^{51)}$ 。非付与側咀嚼のときは早期接触が平衡側 で接触するが，付与側咀嚼時に比べ弱い力で接触 することになるため早期接触の位置による影響が でにくかったものと思われる。また，ほとんどの 被験者が非付与側咀嚼のほうが付与側咀嚼に比べ 咀嚼しやすいと述べて抢り，早期接触の影響が少 ないことが推測される。 


\section{（3）下顎運動}

ガム咀嚼時の下顎運動路は, 早期接触付与によ り咀嚼側に偏位した形を描く傾向を示した。

早期接触の位置による変化は, 閉口路について は付与側咀嚼の場合著明ではなかったが，早期接 触が後方に移動するに従い，付与側により偏位す る傾向を示すものがあった。また，非付与側咀嚼 では早期接触の位置による変化はほとんどなかっ たが，やや非付与側に偏位する傾向を示すものが あった。

開口路については閉口路と同様で付与側, 非付 与側咀嚼とも，早期接触が後方に移動するに従 い, 咀嚼側に偏位する傾向がみられた。特に, 被 験者 Cでは付与側咀嚼において早期接触が大臼歯 部にあるときは，開口路が閉口路よりもより側方 を通る運動路が多かった（図23）。

林 ${ }^{19)}$ は早期接触付与後, これを避计ようとして 閉口するためか運動路の側方移動量が增大する ことを認めている。ま, 顎機能異常者では下顎運 動路は一般に複雑な形態を示し52)，開閉口路の

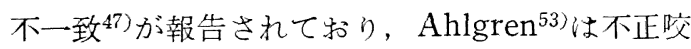
合および咬合干渉があるものでは cross pattern や reverse pattern が多く,さらに不規則であっ たと報告している。本研究では，早期接触が大日 歯部にある場合にこれらの報告と同様の所見が多 く認められた。

付与側咀嚼では, 早期接触部に対して多くの場 合，筋活動の項でも述べたように無意識に強い力 が加わらぬような防御反応によって，また片側指 示咀嚼を行わせたため咬みにくいのを不本意なが らあえて咬むためか，付与側に偏位した閉口，開 口運動が行われたものと考えられる。そして早期 接触が後方に移動するに応じて，各部で上記のこ とが起こることになり，後方歯ほど下顎を側方一 より大きく動かさなければならず，切歯部でみた 運動路の側方移動量は概して大きくなったのであ ろう。

また非付与側咀嚼では，付与側は平衡側になり 運動終末位付近においてその早期接触が直接関与 することになる。これが関与しない範囲では, 運
〈箸好側咀稻〉

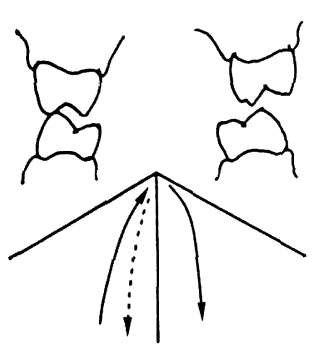

〈非嘫好㒋咀嚼〉

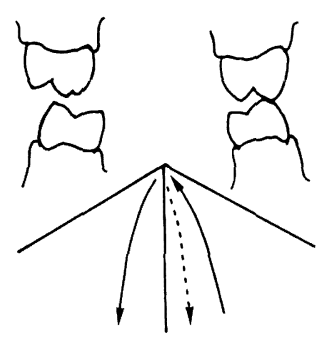

〈付与側咀嚼〉

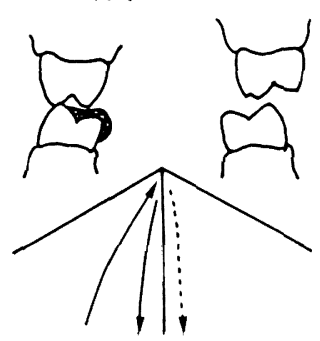

非付与側咀嚼

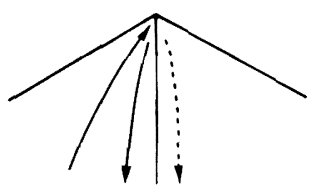

4
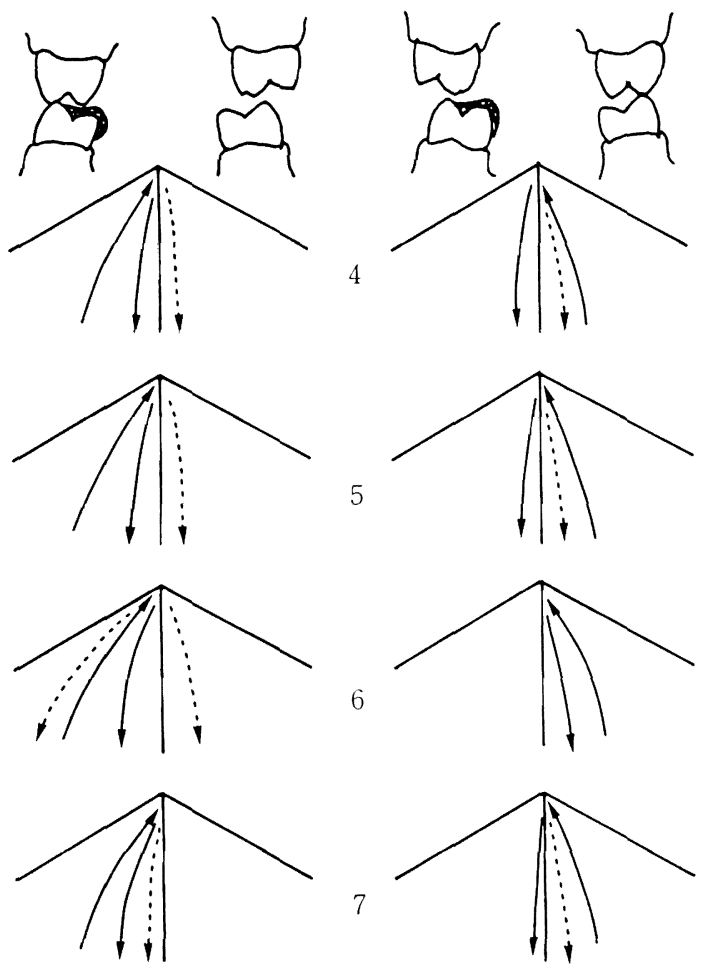

図23 ガム咀嚼時の下顎運動路
4 : 第一小罒闲付与
5 : 第二小臼蔽付与
6: 第一大田紫付与
7 : 第二大妇䉼付与

動路は早期接触を付与してないとき（非嗜好側咀 嚼）とほとんど同じであるが，終末位付近ではこ れを避故るらな,やはり非付与側に偏位した形 の運動路になるのではないかと思われる。

なお，これらの場合に咬頭干渉による下顎の僱 位に詨して考光られている ${ }^{41)}$, lateral jaw move. 
ment reflex ${ }^{54)}$ が时少しているかもし机ない。

いずれにしても，古!期接触を付与することによ り叫嚼速動は変化し，一般に吅嚼側に㑲位した迎 秒路を落くようであ门，ての程度は概して早期接 触が侵方にある汪ど著しい倾问があるといえる。

\section{V. 結}

論

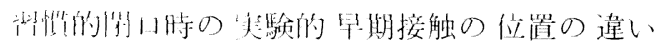
が, 咀㗖筋 (收筋; $\mathrm{Mm}$, 側頭筋前部; $\mathrm{Ta}$, 側頭 筋後部； Tp）の㙨能，および下䫟運動に及ぼす 影刻を明らかにするため，6人の被験者について

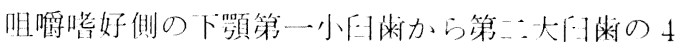

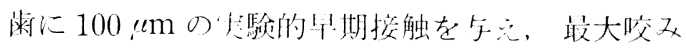

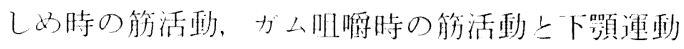
を测定し唡时した絬果，以下の絬論を得た。

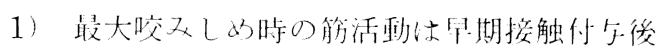

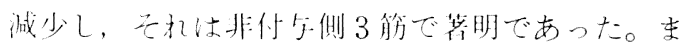
た，早期接触が大下嗉部上りも小目蔽部にあると きのほらが付与側の3 筋の活動此辩が大きい被駼 者が多かった。

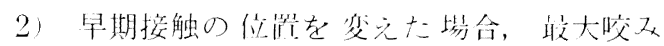
しめ時の各筋の IP 比の変化は Tp で著明であっ た。早期接触が後方に移動するに捝い付与側の TpのIP 比は小さなり, 非付与側の Tp の IP 比は大寺后なる被娩者が多かった。 Taは 问じ倾向を示すものが多く, Mm は Tpや Taに

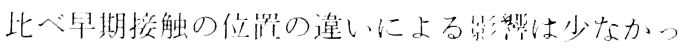
た。

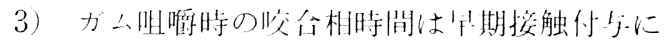
より知秎する优们を示したが，早期接触が後方に 移動するに推い, 付与側, 非付与側いずれの咀嚼 でもより短編する倾问がスられた。閉山相時間は

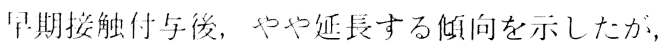
開山相時間恃延坛するものと短赫するものがあっ た。いずれも早期接触の位置の違いによる影愁は 少なかった。

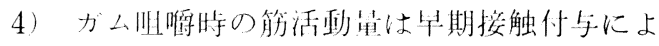
り娍少するものが多かったが，增大寸るものもあ

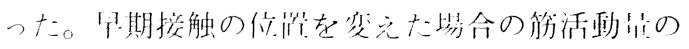

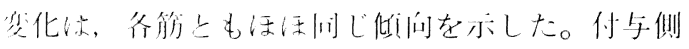

咀嚼では閉口相の管活政量は早期接触が後方に移 動するに従い増加し，また咬合相の筋活動量は早 期接触が第一大曰消にあるとさに最も減少する被 験者が多かった。非付与側咀嚼では早期接触の位 䍜の影響は少なかった。

5）ガム咀嚼時の下顎の運動路は, 付与側, 非 付与側のいずれの咀嚼においても, 開閉口路とも ほとんど咀嚼側に偏位した形を描くが，早期接触 が後方に移動するに従い，上り咀嚼側に偏位する 倾向があった。

\section{謝辞}

稿を終えるに臨み，ご愁篤なるご指導とご校閱を賜 りました藍稔教授に临んで感謝の意を表します。

また，研究に際し、種々ご助言, ご協力をいただ きました学粕科補経学第 1 講座の諸先生方, ならび に被䮖者の方々に心上り㧍礼申しあげます。

本研究の要旨の一部は, 昭和63年10月, 第80回日本 補経载科”会学術大会に扮いて報告した。

\section{文献}

1）藍 稔：顎機能異常一盿合からのアプローチ. 東京, 1983，医蔽薬出版，1-322.

2) Porrit, J. E. : Electromyographic Study Involving Occlusal Interferences. Am. J. Orthodontics $46: 57-58,1960$.

3) Schaerer, P., Stallard, R. E. and Zander, H. A. : Occlusal interferences and mastication: An electromyographic study. J. Prosthet. Dent. 17 : 438-449, 1967.

4) DeBoever, J. : Experimental occlusal balancing -contact interference and muscle activity. Parodontologie $23:$ 59-69, 1969.

5）豊阔博夫, 藤岡道治, 長沢 亭, 津留宏道: 幽 冠修復物による早期接触に関する筋電図学的研 究. 補経誌 $16: 433-434,1973$.

6）遊佐秀顕：咬合時の顎笳反射に関する筋電汹学 的研究. 歯学 $61: 800-809,1973$.

7）佐藤文彦，林 和彦，佐藤義廣，加藤 笪，石 川純：早期接触の咀嚼系に及ぼす影響（第一 被)。日葜周誌 $16: 321-327,1974$.

8）高橋禎生：㬰験的咬合障害に関する EMG。将 学 $62: 58-90,1974$.

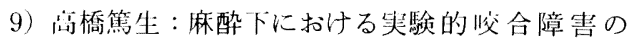
EMG. 歯学 62:91-105, 1974.

10) Randow, K., Carlsson, K., Edlund, J. and Öberg, $T$. : The effect of an occlusal interference on 
the masticatory system. Odont. Revy. 27 245-256, 1976.

11）田中伐平：咬頭嵌合位における補経物の高さが 罘口腔系に及ぼす影䇾。補経誌 $19: 666-692$, 1976.

12）小川晴彦: 実験的咬合干渉が咀嚼筋笳電図の時 間的要素に及注寸影艟. 歯科医学 39：421$440,1976$.

13）小林條太郎：実験的咬合障害における顎筋反射 の筋電図学的研究. 歯学 $64: 612-626,1976$.

14）犬伏義臣：雬根周用の感覚が咬筋 EMG の Silent Period に及ぽす影響について。歯科医学 40 : 743-762, 1977.

15）羽田 勝, 柄 博治, 山内和夫：実験的早期接 触が咀嚼機能に及ぼす影響。広大齿誌 10 ： 246-263, 1978.

16）垂水 绦：実験的咬合干涉が睡服中の咀嚼筋活 動に及ほす影響. 歯科医学 41 : 191-210, 1978.

17) 関根紀彦：実験的早期接触が咀嚼笳 EMG bur-

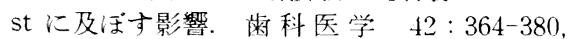
1979.

18) Bakke, M. and M $\phi$ ller, E. : Distortion of maximal elevator activity of unilateral premature tooth contact. Scand. J. Dent. Res. $80: 67-75$, 1980.

19）林 清平：実験的咬合干涉が咀嚼采に与える影 響. 歯学 $70: 687-764,1982$.

20) Riise, C. and Sheikholeslam, A. : The influence of experimental interfering occlusal contacts on the postural activity of the anterior temporal and masseter muscles in young adult. J. Oral Rehabil. 9 : 419-425, 1982.

21）桓松克巳：実験的早期接触付与による咀嚼筋 EMG の経時的変化. 補経誌 $27: 784-801$, 1983.

22) 武田悦孝：ヒトの睡眠中の Bruxism に関する 臨床的研究一実験的咬合干涉付与前, 付与後, 除去後に打梳子筋電図, 脳電図, 眼球運動図, 心電図，呼吸曲線，精神内分泌の反応，ならび に臨床所見の経日的比較検討一. 歯学 71 : 276-337, 1983.

23) Sheikholeslam, A. and Riise, C. : Influence of experimental interfering occlusal contacts on the activity of the anterior temporal and masseter muscles during submaximal and maximal bite in the intercuspal position. J. Oral Rehabil. $10: 207-214,1983$.

24) Hannam, A. G., Wood, W. W., De Cou, R. E. and Scott, J. D. : The effects of working-side occlusal interferences on muscle activity and associated jaw movement. Archs. Oral Biol. $26: 387-392,1981$.

25）関野 真：実験的咬合障害が咀嚼筇活動に及ぼ

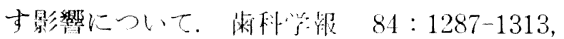
1984.

26) Riise, C. and Sheikholeslam, A. : Influence of experimental interfering occlusal contacts on the activity of the anterior temporal and masseter muscles during mastication. J. Oral Rehabil. 11 : 325-333, 1984.

27) Rugh, J. D., Barghi, N. and Drago, C. J. : Experimental occlusal discrepancies and noctural bruxism. J. Prosthet. Dent. 51 : 548-553, 1984.

28）萩原 彰, 小林義典：ヒ卜の腄眠中の Bruxism に関寸る臨床的研究一水平的実駼的咬合干涉付 与前, 付与後, 除去後に挍汁万筋電龱, 脳電龱, 眼球電龱, 心電図, 呼吸曲線, 臨床所見, なら びに精神内分泌反応の経日的分析一。清学 73 : 946-1019, 1985.

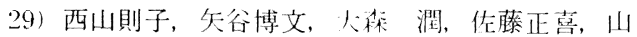
下 敦：簡易型筋電計 EM-2 の臨床応用の可

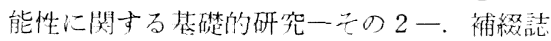
32 : 249, 1988

30) Funakoshi, M., Fujita, N. and Takehana, S. : Relations Between Occlusal Interference and Jaw Muscle Activity in Response to Changes, in Head Position. J. Dent. Res. 55: 684-690, 1976.

31）小林義典, 武旧悦孝, 石原裕之：実験的晈合干

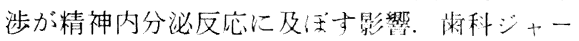
ナル $23: 285,1986$

32) Noble, W. H. and Martin, L. P. : Tooth mobility changes in response to occlusal interferences. J. Prosthet. Dent. $30: 412-417,1973$.

33) Ramfjord, S. P. : Dysfunctional Temporomandibular Joint and Muscle Pain. J. Prosthet. Dent. $11: 353-374,1961$.

34）柴田考典, 中沢勝宏, 尾崎佳孝, 增间健, 小 鹿典雄: ビジブル・ハイオフィードバック機能 を持つ下顎運動解析装置+ホンビジトレーナー C IIについて. 補緅臨床 14：101-116，1981.

35）曽根田兼司：上顎犬畨舌面の傾斜角度の違いが 咀嚼笳活動に及ぼす影響。 口病誌 56 : 162181， 1989.

36）水谷紘, 篠ヶ谷龍哉, 畺根田兼司, 礒和博, 藍稳：畨の接触関釈が咬筋, 側頭筋の活動 に及ぼす影犁第 1 報 総活動量と㕮頭嵌合位 における最大呚及しめ值に対する比率 (IP 比). 補緅誌 33：1062-1071， 1989.

37) Geering, A. H. : Occlusal interferences and functional disturbances of the masticatory system. J. Clin. Periodontol. 1 : 112-119, 1974.

38）坂東永一，四中伐平：生体側から又た精度。補 綴臨床別冊／調節性咬合器一クラウン・ブリッ ジのために一、東京, 1977 , 医歯薬出版, 147158. 
39）礒 和博：支持点の位置が咬合力，咀嚼筋活動 に及ほす影稳に関する研究。口病誌 49 :168一 190, 1982.

40）三谷春你：筋電計による咀嚼筋活動の診査. 迷 科ジャーナル $16: 307-317,1982$.

41) Ramf jord, S. P. and Ash, M. M. : オクルーショ ン咬合治療の理論と臨床，鸴道幸男，三谷春 保, 所田典治共訳, 東京, 1986, 医歯薬出版, $1-263$.

42) 藍 稔：切噛点部にお㚈る咀嚼運動の解析. 補緅誌 6 : 164-200, 1962.

43) Hosman, H. and Naeije, M. : Reproducibility of the normalized electromyographic recordings of the masseter muscle by using the EMG recording during maximal clenching as a standard. J. Oral Rehabil. $6:$ 49-54, 1979.

44）小笠原浩一：支持点の違いが下䫇の変位, 咀嚼 筋活動に及ほす影響に関する研究. 口病誌 53 : 81-101, 1986.

45) MacDonald, J. W. C. and Hannam, A. G. : Relationship between occlusal contacts and jaw-closing muscle activity during tooth clenching. Part II. J. Prosthet. Dent. 52: 862867, 1984.

46）橋本猛伸：巨歯補綴の効果に関寸る筋電図学的 研究. 杵科医学 32 : 58-92, 1969.

47）加藤信次：嚬関節機能障害患者の切歯点におけ る咀嚼運動について。歯科医学 $41: 117-146$,
1978.

48）Körber, K.：ケルバーの補綴学 (第一巻). 田端 恒雄, 河野正司, 福島俊士共訳, 東京, 1982, クインテッセンス出版, 245-365.

49) Anderson, D. J. and Picton, D. C. A. : Masticatory stresses in normal and modified occlusion. J. Dent. Res. $37:$ 312-317, 1958.

50) Hiiemae, K. M. : Mammalian mastication : A review of the activity of the jaw muscles and the movements they produce in chewing. In Development, Function and Evolution of Teeth. (Eds.) Butler, P. M. and Josey, K. A., London, 1978, Academic Press, 359-398.

51) DeBoever, J. A., McCall, W.D., Holden, S. and Ash, M. M. : Functional occlusal forces : An investigation by telemetry. J. Prosthet. Dent. $40: 326-333,1978$.

52) Atkinson, H. F. and Shepherd, R. W. : Temporomandibular joint disturbances and the associated masticatory patterns. Aust. Dent. J. 6 : 219-222, 1961.

53) Ahlgren, J. : Pattern of chewing and malocclusion of teeth. A clinical study. Acta Odontol. Scand. $25: 3-13,1967$.

54) Lund, J. P., McLachlan, R. S. and Dellow, P. G. :A lateral jaw movement reflex. Exp. Neurolo. $31: 189-199,1971$. 